\title{
Al-hijamah and oral honey for treating thalassemia, conditions of iron overload, and hyperferremia: toward improving the therapeutic outcomes
}

\author{
This article was published in the following Dove Press journal: \\ Journal of Blood Medicine \\ 30 October 2014 \\ Number of times this article has been viewed
}

\begin{abstract}
Salah Mohamed El Sayed ${ }^{1,2}$
Hussam Baghdadi ${ }^{2}$

Ashraf Abou-Taleb ${ }^{3}$

Hany Salah Mahmoud ${ }^{4}$

Reham A Maria ${ }^{2,5}$

Nagwa S Ahmed'

Manal Mohamed Helmy Nabo ${ }^{6,7}$

'Department of Medical Biochemistry, Sohag Faculty of Medicine, Sohag University, Sohag, Egypt; ${ }^{2}$ Department of Clinical Biochemistry and Molecular Medicine, Taibah Faculty of Medicine, Taibah University, Al-Madinah Al-Munawwarah, Kingdom of Saudi Arabia; ${ }^{3}$ Department of Pediatrics, Sohag Faculty of Medicine, Sohag University, Sohag; ${ }^{4}$ World Federation of

Alternative and Complementary Medicine, Cairo Regional Headquarter, Cairo; ${ }^{5}$ Department of Medical Biochemistry, Tanta Faulty of Medicine, Tanta University, Tanta; ${ }^{6}$ Department of Pediatrics, Sohag Teaching Hospital, Sohag, Egypt; ${ }^{7}$ Division of Pediatric Cardiology, Department of Pediatrics, Maternity and Children Hospital, King Abdullah Medical City, Al-Madinah Al-Munawwarah, Kingdom of Saudi Arabia
\end{abstract}

\section{Video abstract}

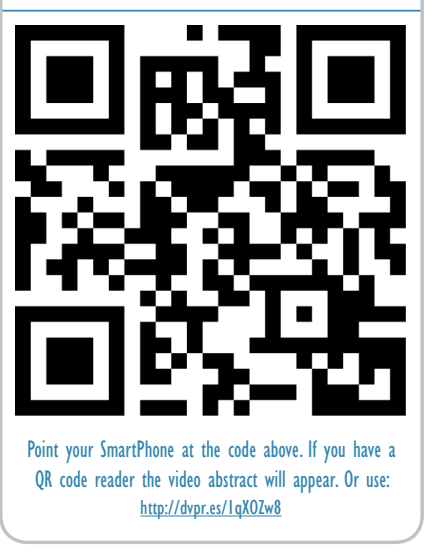

Correspondence: Salah Mohamed El Sayed Department of Medical Biochemistry, Sohag Faculty of Medicine, Sohag University, Egypt $\mathrm{Tel} / \mathrm{fax}+2934602963$

Email drsalahpediatr@yahoo.com
Abstract: Iron overload causes iron deposition and accumulation in the liver, heart, skin, and other tissues resulting in serious tissue damages. Significant blood clearance from iron and ferritin using wet cupping therapy (WCT) has been reported. WCT is an excretory form of treatment that needs more research efforts. WCT is an available, safe, simple, economic, and time-saving outpatient modality of treatment that has no serious side effects. There are no serious limitations or precautions to discontinue WCT. Interestingly, WCT has solid scientific and medical bases (Taibah mechanism) that explain its effectiveness in treating many disease conditions differing in etiology and pathogenesis. WCT utilizes an excretory physiological principle (pressure-dependent excretion) that resembles excretion through renal glomerular filtration and abscess evacuation. WCT exhibits a percutaneous excretory function that clears blood (through fenestrated skin capillaries) and interstitial fluids from pathological substances without adding a metabolic or detoxification burden on the liver and the kidneys. Interestingly, WCT was reported to decrease serum ferritin (circulating iron stores) significantly by about $22.25 \%$ in healthy subjects (in one session) and to decrease serum iron significantly to the level of causing iron deficiency (in multiple sessions). WCT was reported to clear blood significantly of triglycerides, low-density lipoprotein (LDL) cholesterol, total cholesterol, uric acid, inflammatory mediators, and immunoglobulin antibodies (rheumatoid factor). Moreover, WCT was reported to enhance the natural immunity, potentiate pharmacological treatments, and to treat many different disease conditions. There are two distinct methods of WCT: traditional WCT and Al-hijamah (WCT of prophetic medicine). Both start and end with skin sterilization. In traditional WCT, there are two steps, skin scarification followed by suction using plastic cups (double $\mathrm{S}$ technique); Al-hijamah is a three-step procedure that includes skin suction using cups, scarification (shartat mihjam in Arabic), and second skin suction (triple $\mathrm{S}$ technique). Al-hijamah is a more comprehensive technique and does better than traditional WCT, as Al-hijamah includes two pressure-dependent filtration steps versus one step in traditional WCT. Whenever blood plasma is to be cleared of an excess pathological substance, Al-hijamah is indicated. We will discuss here some reported hematological and therapeutic benefits of Al-hijamah, its medical bases, methodologies, precautions, side effects, contraindications, quantitative evaluation, malpractice, combination with oral honey treatment, and to what extent it may be helpful when treating thalassemia and other conditions of iron overload and hyperferremia.

Keywords: Al-hijamah, prophetic medicine, cupping therapy, phlebotomy, iron chelation therapy, oral honey

\section{Introduction}

Cupping therapy is the term given to treatment modalities using sucking cups that are applied to the skin surface at different anatomical points. It includes both dry cupping 
therapy (DCT) and wet cupping therapy (WCT). WCT is an excretory form of treatment that needs more research as a safe, economic, time-saving technique without serious side effects. ${ }^{1}$ WCT does not require sophisticated equipment, expensive disposables, or extensive effort to practice. ${ }^{1}$ There are no serious limitations, precautions, or side effects to discontinue WCT. Interestingly, WCT has solid scientific and medical bases that explain its effectiveness in treating many disease conditions differing in etiology and pathogenesis according to the evidence-based Taibah mechanism (Taibah theory) $)^{1}$ (Supplementary video 1). WCT includes both the traditional WCT (skin scarification and suction method), and the more comprehensive WCT of prophetic medicine, Al-hijamah (skin suction, scarification, and suction method). We will discuss here some reported hematological and therapeutic benefits of WCT, its medical basis, methodologies, WCT-induced reduction in serum iron and ferritin, combination with oral honey, and to what extent this may be helpful when treating thalassemia, hemochromatosis, sideroblastic anemia, and other conditions of iron overload and hyperferremia.

\section{Important reported therapeutic and hematological benefits of WCT}

A single session of WCT (blood cupping therapy, Al-hijamah) was reported to decrease serum ferritin (circulating iron stores) significantly by about $22.25 \%$ in healthy subjects (from $129 \pm 59.2$ to $100.6 \pm 45.8 \mathrm{ng} / \mathrm{mL}$ ). ${ }^{2}$ The same session of WCT cleared blood significantly of triglycerides, lowdensity lipoprotein (LDL) cholesterol, total cholesterol, and uric acid. ${ }^{2}$ In rheumatoid arthritis, WCT cleared patients' blood of immunoglobulin antibodies (rheumatoid factor) in a time-dependent manner, ${ }^{3}$ which may increase the therapeutic benefits of WCT. In another report, frequent WCT was reported to decrease serum iron, causing iron deficiency that brought about iron deficiency anemia. ${ }^{4}$

Potentiation of the natural immunity in the form of physiological leukocytosis and an increased number of natural killer cells were reported after applying WCT. ${ }^{3}$ That was confirmed by the study of Zhang et al, who reported that traditional WCT decreased serum levels of the immune inhibitory cytokines (eg, immunoglobin $\mathrm{E}$ [ $\operatorname{IgE}]$, interleukin-4 [IL-4], IL-10) and decreased the number of T cytotoxic cells (CD8+) cells. In the same subjects, WCT increased the production of endogenous immunostimulatory cytokines (eg, interferon-gamma, IL-2, complement-3, complement-4, immunoglobulins [IgA, IgG, and IgM]) and activated cells of the immune system (eg, T helper cells), causing an increased ratio of T helper/T cytotoxic cells, ${ }^{5}$ which may help in treating hepatitis viral infections that may complicate frequent blood transfusions.

Being a mechanical modality of treatment, WCT has no chemical or pharmacological antagonism with pharmacological treatments such as iron chelation therapeutics. As mentioned before, WCT was reported to clear blood significantly of excess pathological substances, which may facilitate and potentiate the related pharmacological and therapeutic effects of coadministered pharmacotherapy. ${ }^{1}$ Moreover, WCT was reported to significantly decrease the blood pressure, and improve the lipid profile and treat different diseases, such as hypertension and hyperlipidemia., WCT was reported to exert pharmacological potentiation when treating different diseases and to alleviate druginduced side effects; ${ }^{1,3}$ for example, WCT-induced leukocytosis counteracted methotrexate-induced leucopenia when treating rheumatoid patients with Al-hijamah combined with methotrexate. ${ }^{1,3}$ Interestingly, skin wounding (eg, the minor skin scarifications done during WCT) was reported to enhance the production of endogenous nitric oxide through upregulating the expression of nitric oxide synthase (NOS). ${ }^{1,6}$ Neuronal NOS messenger ribonucleic acid (mRNA) is upregulated and neuronal NOS protein expression peaks at the late stages of skin wound healing. ${ }^{7}$ Moreover, inducible NOS mRNA was reported to increase by about tenfold, ${ }^{8}$ peak 24 hours after wounding, and persist for a few days. ${ }^{9}$ Nitric oxide exerts many important roles, including antioxidant effects, ${ }^{10}$ vasodilator functions, and antimicrobial effects, ${ }^{11}$ among others. ${ }^{1}$ Recently, Alhijamah was reported to exert multiple therapeutic health benefits; for example, nonspecific biochemical clearance of serum and interstitial fluids, excretory benefits, antinociceptive (analgesic) effects, anti-inflammatory effects, hemodynamic effects, antiviral effects, anticancer effects, antiallergic effects, respiratory benefits, and neurological health benefits. Moreover, Al-hijamah was reported to exert nonspecific-tissue protective benefits, cardioprotective effects, hepatoprotective benefits, nephroprotective effects, and neuroprotective effects, among others. Therefore, the reported antihypertensive and antihyperlipidemic effects of Al-hijamah may be beneficial in guarding against the development and progression of premature atherosclerosis that is encountered in some diseases, such as thalassemia. We reported Al-hijamah as a promising suggested treatment for hematological conditions characterized by iron overload; eg, hemochromatosis, thalassemia, sideroblastic anemia, and others. ${ }^{11}$ 


\section{Indices for evaluating therapeutic effects of Al-hijamah}

Recently, we reported the novel therapeutic indices of Alhijamah for evaluating the health benefits gained from practicing Al-hijamah for treating different disease conditions. ${ }^{11}$ Such indices included excretion index, purification index, immunological potentiation index, pharmacological potentiation index, and clinical therapeutic index (CTI).

Excretion index (excretion value, EV) is the quantity of noxious substances excreted after the end of the session of Alhijamah in quantity units/volume units. EV can be calculated by determining the difference in levels of noxious substances before and after Al-hijamah (in quantity units/volume units). An example for that was the decrease in serum ferritin from $129.4 \mathrm{ng} / \mathrm{mL}$ (before Al-hijamah) to $100.6 \mathrm{ng} / \mathrm{mL}$ (after Al-hijamah):

$$
\mathrm{EV}=(129.4-100.6=28.8 \mathrm{ng} / \mathrm{mL}) .
$$

Plasma clearance index, or purification index (PI), is the percentage of purification of plasma from any noxious substance or component estimated at different time points after Al-hijamah. PI can be calculated by estimating the difference in the concentration of a noxious substance before and after Al-hijamah divided by its initial plasma concentration level. Using the abovementioned example, PI for plasma from serum ferritin equals

$$
100 \times(129.4-100.6=28.8 \mathrm{ng} / \mathrm{mL}) / 129.4=22.25 \% .
$$

This means that Al-hijamah induced clearance of more than one-fifth of initial serum ferritin in a single session, which may be promising when treating conditions of iron overload.

Pharmacological potentiation index measures the degree of pharmacological potentiation gained when conventional pharmacological treatments are administered concomitantly with practicing Al-hijamah. It also compares the gained therapeutic benefits versus using conventional pharmacological treatment as a sole treatment. When treating rheumatoid arthritis patients using conventional pharmacological treatment, the initial serum rheumatoid factor was 129.75 to $131.47 \mathrm{IU} / \mathrm{mL}$, which decreased to $122 \mathrm{IU} / \mathrm{mL}$ when conventional pharmacological treatment was used as a sole treatment. ${ }^{3}$ A combination of conventional pharmacological treatment plus Al-hijamah caused serum rheumatoid factor to decrease to $51.46 \mathrm{IU} / \mathrm{mL}$. Pharmacological potentiation index for decreasing serum rheumatoid factor:

$$
[100 \times(131.47-51.46) /(129.75-122)]=1,032 \% .^{11}
$$

Thus, combining Al-hijamah with pharmacological treatment increased the gained therapeutic effects more than ten times.

Immunological index measures the degree of immunological potentiation gained after Al-hijamah; eg, natural killer cell lymphocytosis. It can be calculated by measuring the number of natural killer cells before and after Al-hijamah. A percentage count of natural killer cells before Al-hijamah was $8.5 \%$ and increased to $11.33 \%$ after Al-hijamah. II for the increase in the count of natural killer cells can be calculated as

$$
[100 \times(11.33 / 8.5)]=133 \% .
$$

Thus, natural immunity using natural killer (NK) cells increased by about $133 \%$ after Al-hijamah.

CTI is the improvement percentage of an investigated clinical parameter (eg, diastolic blood pressure value, systolic blood pressure value, pain intensity value, disease activity value, and others) after Al-hijamah (as a sole treatment or as a combined treatment) was measured at different time points versus the same value before Al-hijamah. Diastolic blood pressure was $81.1 \mathrm{mmHg}$ before Al-hijamah and significantly decreased to $75 \mathrm{mmHg}$ after Al-hijamah. ${ }^{2}$ The improvement in diastolic blood pressure equals

$$
(81.1-75)=6.1 \mathrm{mmHg} \text {. }
$$

When calculating the percentage improvement versus the initial value of systolic blood pressure, CTI can be derived from the formula:

$$
\mathrm{CTI}=[100 \times 6.1 / 81.1]=7.5 \%{ }^{1}
$$

Thus, diastolic blood pressure decreased by $7.5 \%$ in healthy subjects after Al-hijamah.

\section{Scientific principles of WCT and Al-hijamah}

Making use of simple scientific facts in physiology and histology may improve treatment outcomes. For example, human skin has a superficial network of fenestrated dermal capillaries ${ }^{13}$ (Figure 1A) that may help percutaneous pressure-dependent and size-dependent filtration and blood clearance upon application of external suction pressure; WCT utilizes a physiological filtration and an excretory principle for inducing blood clearance. Capillary pores and fenestrations are 6-12 $\mathrm{nm}$ (and may reach up to $100 \mathrm{~nm}$ in diameter) (Figure 1B), ${ }^{12,14}$ which cannot filter intact blood cells (having diameters in microns). ${ }^{14}$ This may carry a lot of similarities with renal glomerular filtration. This confirms 

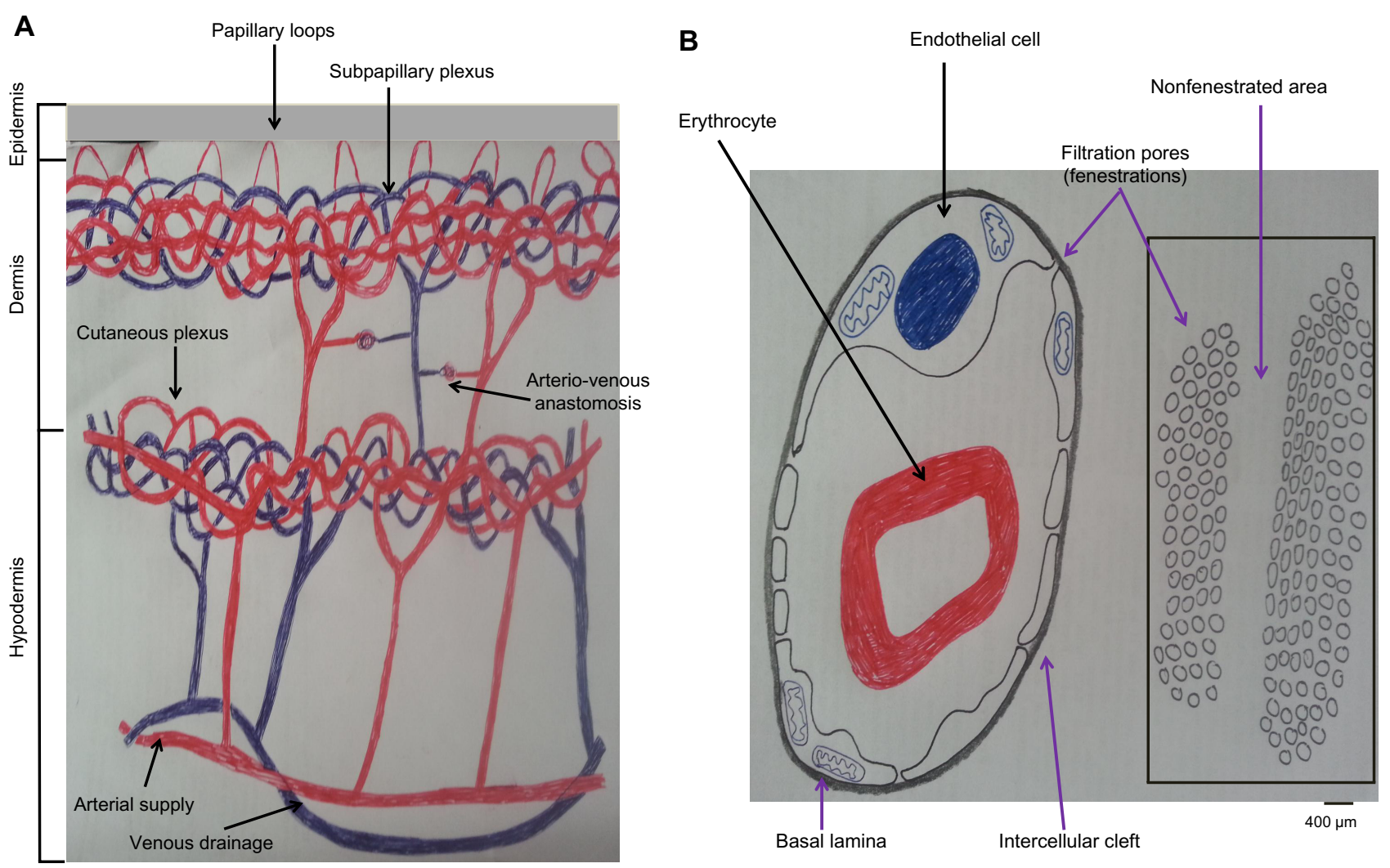

Figure I Skin histology is ideal for practicing wet cupping therapy.

Notes: (A) Epidermis is avascular, while dermis contains subepidermal fenestrated capillary networks suitable for pressure-dependent and size-dependent capillary filtration. Papillary loops are projecting into the epidermis. Subpapillary plexus of capillaries is present in the upper dermis just beneath the epidermis. The larger cutaneous capillary plexus is present at the junction of the dermis and hypodermis. (B) Pores of fenestrated capillaries can filter small molecules, but cannot filter blood cells. Data from Saladin, ${ }^{14}$ Bouwstra et al, ${ }^{15}$ and Young and Heath. ${ }^{16}$

the fact that Al-hijamah utilizes a physiological principle for inducing blood clearance (pressure-dependent filtration followed by excretion) that is better than the chemical methods of blood clearance; eg, dialysis (concentration-dependent excretion). All this constituted the basis for Taibah mechanism (Taibah theory) for scientific basis of Al-hijamah and cupping therapy. ${ }^{1}$

Moreover, skin comprises three layers: epidermis, dermis, and hypodermis. Epidermis is the most superficial layer, and does not contain blood capillaries. The most superficial layer of the epidermis is the horny cell layer that is the keratinized epithelium layer (stratum corneum). This keratinized cell layer constitutes the skin barrier $(10-20 \mu \mathrm{m})$ that provides the function of protecting the skin and the underlying structure through preventing the entry and exit of substances through the skin. Immediately below the stratum corneum, there are the viable epidermal cell layers (50-100 $\mu \mathrm{m}$ thick), which are responsible for generating the stratum corneum. ${ }^{15}$

The dermis (1-2 mm thick) is the second layer of the skin that lies immediately beneath the epidermis. The dermis constitutes the mechanical support for the skin. Unlike the epidermis, the dermis contains fenestrated skin capillaries that are suitable for pressure-dependent filtration upon application of negative suction pressure, as that done during Al-hijamah. ${ }^{15}$ Interestingly, the ultrastructure of the skin vasculature confirms that the arterial blood supply of the skin comes through the cutaneous arteries that run in the hypodermis, then give rise to branches that anastomose to form the cutaneous capillary plexus of capillary networks at the dermis-hypodermis junction. That cutaneous capillary plexus gives rise to the subpapillary plexus of fenestrated capillaries that lie at the dermoepidermal junction. ${ }^{16}$ The subpapillary plexus gives rise to capillary loops in each dermal papilla. Venous drainage of the skin is arranged in plexuses corresponding to the arterial supply. ${ }^{16}$ Based on that, skin scarification done during Al-hijamah should be so superficial as to just open the skin barrier and reach the superficial dermal capillaries.

Scarifying the skin deeply during Al-hijamah is a malpractice that may cause damage to the fenestrated dermal capillaries and impair the filtration function exerted during Al-hijamah, as we will discuss in the side effects and malpractice of Al-hijamah. Huber et $a{ }^{17}$ reported that many different methods for creating 
suction pressure can be utilized for sucking skin inside sucking cups during cupping therapy. However, some variable differences in pressure may occur and govern the proper choice of the most suitable method to exert such suction pressure. Huber et al studied the mean suction pressure produced during mechanical suction, lighter flame $2 \mathrm{~cm}$ suction, lighter flame $4 \mathrm{~cm}$ suction, and alcohol flame, and found that large differences in suction magnitude were produced. Negative suction was $-200 \pm 30$ hecta Pascal $(\mathrm{hPa})(=-150 \pm 23 \mathrm{mmHg})$ when using $2 \mathrm{~cm}$ flame, $-310 \pm 30 \mathrm{hPa}(-232.5 \pm 23 \mathrm{mmHg})$ with $4 \mathrm{~cm}$ flame, $-560 \pm 30 \mathrm{hPa}(-420 \pm 23 \mathrm{mmHg})$ with burning an alcohol-soaked cotton swab, and $-270 \pm 16 \mathrm{hPa}(-202 \pm 12 \mathrm{mmHg})$ with rubber balloon mechanical suction. The pressure produced through the rubber balloon was the easiest technically, moderate in intensity, maximal in safety (not harmful), and was the most reproducible when repeating cupping therapy. ${ }^{17}$

\section{Methods of practicing WCT}

DCT is a one-step therapeutic modality that involves skin suction only and is done mainly for the purpose of pain relief or to stimulate blood flow at a given anatomical area of the human body. ${ }^{11}$ WCT includes both cupping and bloodletting. There are two reported methodologies of WCT: traditional WCT and Al-hijamah (WCT of prophetic medicine). In both, sterilization using alcohol or povidone iodine in a strict aseptic environment is necessary. Traditional WCT has two steps: skin scarification (puncturing) followed by skin suction (cupping); ie, the double S method or puncturing and cupping method of WCT. ${ }^{18}$ Al-hijamah has three main steps: skin suction (cupping step using sucking cups) (Figure 2A-C), skin scarification (puncturing skin) (Figure 3A-C), and second skin suction (cupping) (Figure 4A-C); ie, the triple S method or cupping, puncturing, and cupping method of WCT. ${ }^{1,18}$ The methodology of using traditional WCT for treating many different disease conditions was reported in many published research studies from Germany, ${ }^{19}$ Korea, ${ }^{20}$ and the People's Republic of China. ${ }^{21-24}$ The methodology of traditional WCT described in those published studies is different from Al-hijamah, which was described in reports from Saudi Arabia ${ }^{25}$ and other countries. ${ }^{26,27}$

Each suction step during WCT is a pressure-dependent filtration step; ie, Al-hijamah has two filtration steps versus one filtration step for traditional WCT, which allows also a longer duration of pressure-dependent filtration during Al-hijamah than during traditional WCT. ${ }^{1,18}$ Based on this, Al-hijamah was reported to provide better filtration, better excretory functions, and less blood loss than traditional WCT. ${ }^{18}$

Traditional WCT is a partial form of Al-hijamah; ie, all diseases treated by traditional WCT can be treated by
Al-hijamah. ${ }^{1,11}$ Indications for practicing Al-hijamah were previously reported. ${ }^{11}$ Al-hijamah is indicated whenever an excess noxious substance or fluid is to be removed from plasma and interstitial fluids. Those excess harmful substances may be causative substances for the disease process or pathogenesis; eg, excess uric acid in gout (causing gouty arthritis) and excess iron in thalassemia and iron overload conditions. Both can be referred to as disease-causing substances. When the excess noxious substances are formed during disease pathogenesis; eg, oxidized LDL in thalassemia patients (induced by excess iron), which can be referred to as disease-related substances. Both disease-causing substances and diseaserelated substances can be referred to as causative pathological substances. Al-hijamah is indicated when the serum level of any causative pathological substances increases in blood or interstitial fluids enough to require clearance. ${ }^{11}$ Moreover, other therapeutic benefits of Al-hijamah ${ }^{11}$ may help in treating different disease conditions, such as musculoskeletal pain conditions and neuropsychiatric conditions. ${ }^{11}$

Skin scarification during Al-hijamah (shartat mihjam in Arabic) (Figure 3A) is a vital step, as it opens the skin barrier and transmits the suction pressure to the fenestrated dermal skin capillaries to favor the excretion of local intercellular fluids and capillary filtration, causing excretion of small-sized particles $^{1,18}$ (serum iron, serum ferritin, liberated hemoglobin and fragments of hemolyzed cells excluding intact blood cells) from skin capillary blood (Figure 1B). Shartat mihjam refers to the superficial skin scarifications $(0.1 \mathrm{~mm}-0.2 \mathrm{~mm}$ in depth) that open the skin barrier to transmit the suction pressure around skin dermal capillaries to facilitate the suction-induced, pressure-dependent filtration process of blood circulating in the fenestrated skin capillaries during Al-hijamah. The superficial nature of skin scarifications ensures that no damage will occur to the fenestrated skin capillaries, which ensures preservation of the pressure-dependent filtration function. To ensure the superficial nature of the skin scarifications, skin incisions done during shartat mihjam should be short (1-2 mm) in length, vertical, in parallel rows, multiple, evenly distributed, confined to the skin uplifting (skin dome), and preceded and followed by a suction step. All that may guarantee the superficial nature of skin scarification and the best conditions for transmitting the negative suction pressure to the fenestrated dermal skin capillaries. Skin scarifications done during traditional WCT cannot be described as shartat mihjam, as those scarifications are not preceded by a suction step. ${ }^{11}$ Filtered fluids (plasma-like fluids) may come out through shartat mihjam with repeated suctions using sucking cups (Figure 4C). Al-hijamah has been reported to exert a percutaneous nonspecific clearance 


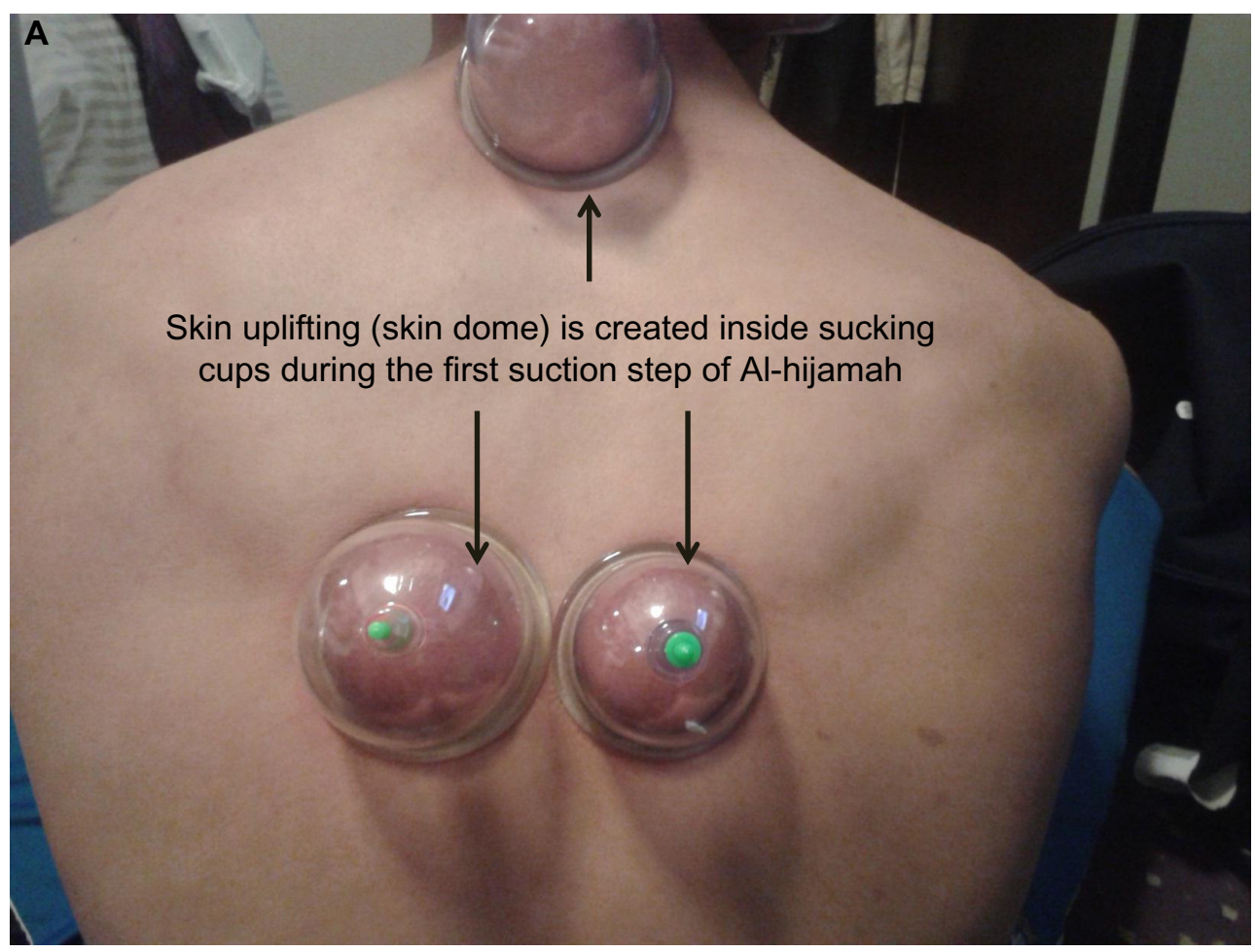

\section{B}

Sucking cup is put at Kahel region

(upper part of the back of the trunk at the skin overlying the seventh cervical vertebra)

Skin upliftings in the interscapular regions

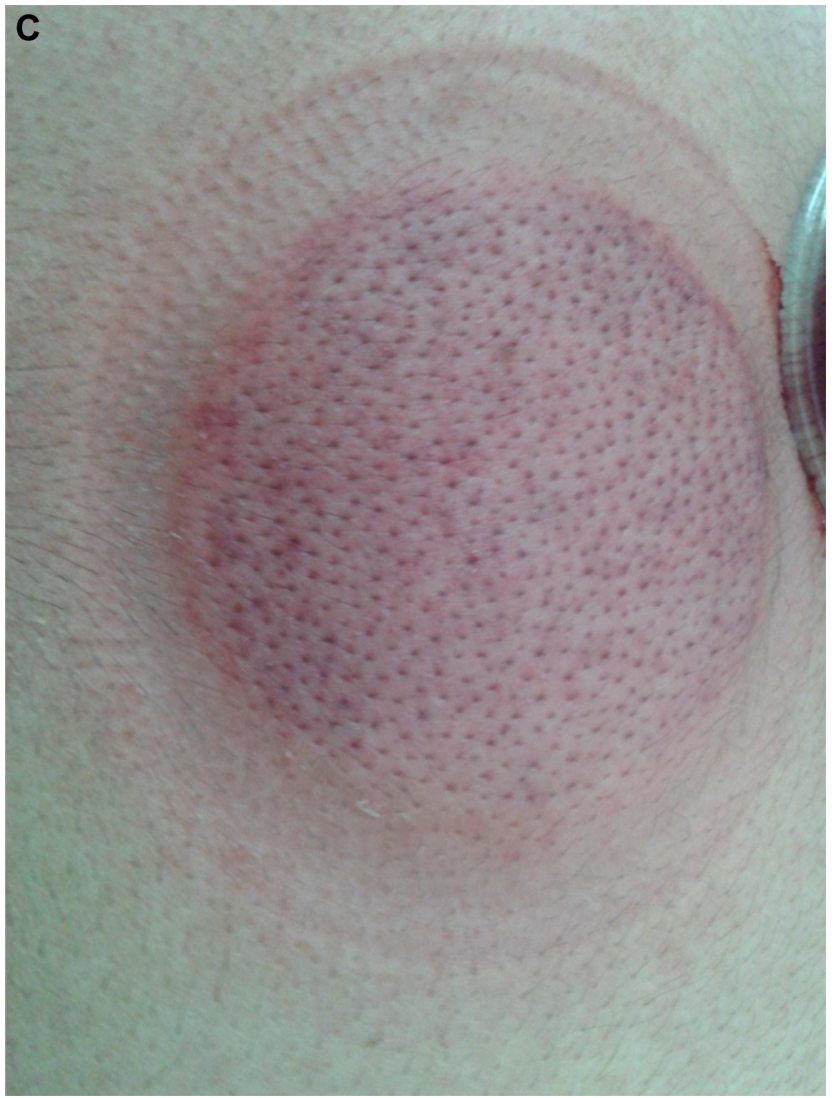

Figure 2 First step of Al-hijamah (first suction step).

Notes: (A) Cups are put mainly at the interscapular regions and upper aspect of the back of trunk (Kahel region over seventh cervical vertebra). ${ }^{28}$ (B) Skin upliftings are created and become prominent after removal of cups. (C) Hair follicles become more prominent within the skin upliftings. 

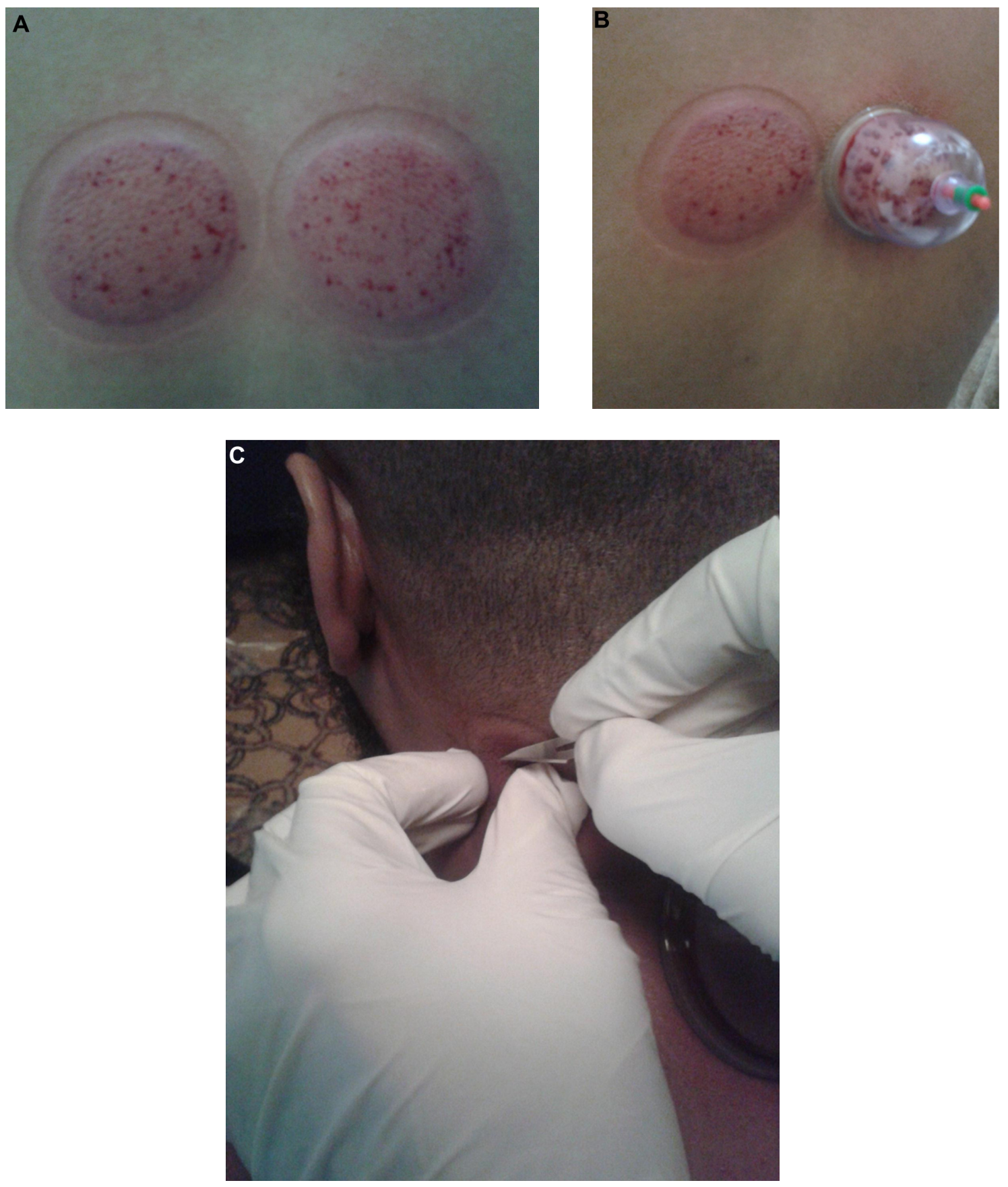

Figure 3 Second step of Al-hijamah (skin scarification, shartat mihjam in Arabic).

Notes: (A) Skin scarifications should be confined to skin upliftings, superficial (0.I-0.2 mm in depth), short (I-2 mm in length), multiple, and evenly distributed. (B) Cups should be applied immediately after scarifying skin upliftings. (C) Salah's technique ${ }^{28}$ for safe practice of Al-hijamah at special anatomical sites: a simple technique aiming at avoiding possible injury of the underlying anatomical structures (eg, nerves or blood vessels during skin scarification step during Al-hijamah). A fold of the skin uplifting is pinched out between the thumb and index fingers of the left hand to make sure that it is away from the underlying anatomical structures, while the right hand makes superficial scarifications in the pinched out skin fold. Another skin fold is then taken, and so on until finishing the skin uplifting properly.

of blood and interstitial spaces. ${ }^{1,2,11,18}$ Increasing the number of Al-hijamah sessions or sucking cups at many anatomical sites may increase blood clearance.

Al-hijamah, also called bloodletting cupping therapy ${ }^{3}$ or blood cupping therapy in Arabic countries, ${ }^{2}$ is a simple therapeutic modality of WCT that is practiced for treating many diseases. Health professionals practicing Al-hijamah should receive adequate medical education and evaluation. Unfortunately, few research studies have focused on Al-hijamah. Detailed scientific bases of Al-hijamah were 

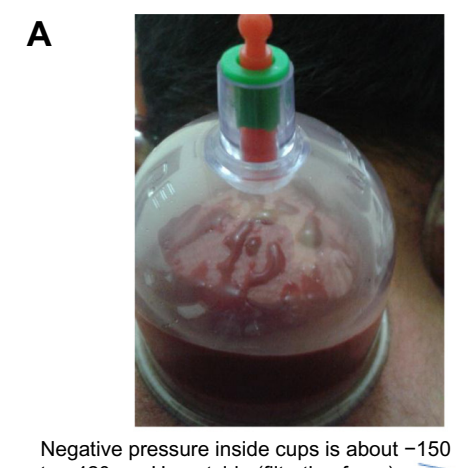
to $-420 \mathrm{mmHg}$ outside (filtration force)

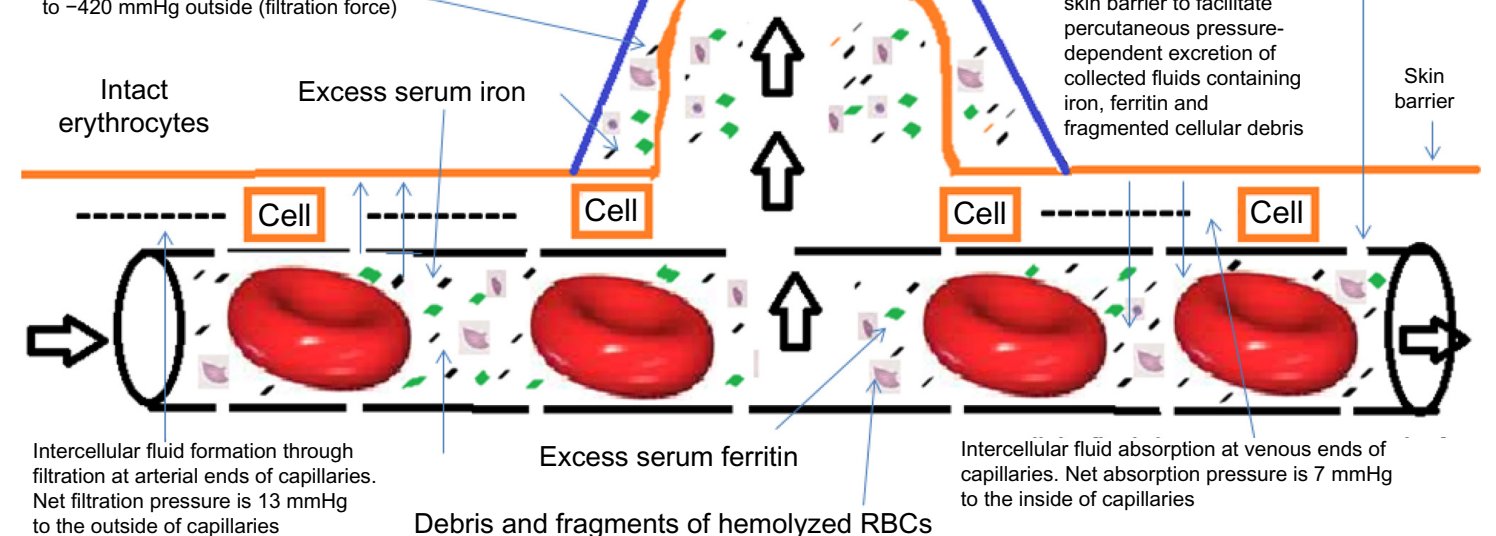

Net filtration pressure is $13 \mathrm{mmH}$ to the outside of capillaries

Debris and fragments of hemolyzed RBCs

Filtration

pores

(fenestrations)

Fenestrated skin capillaries
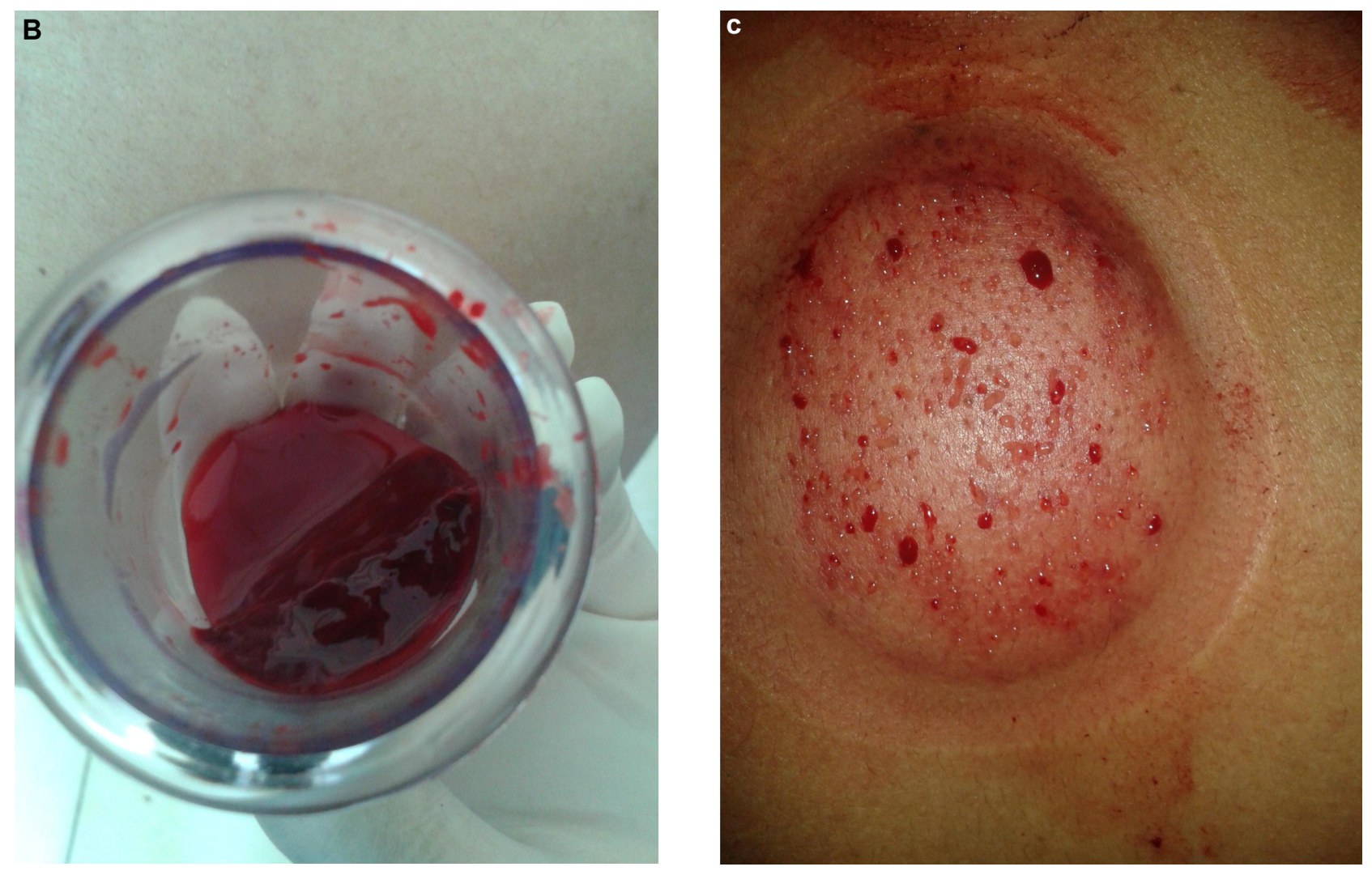

Figure 4 Third step of Al-hijamah (second suction step).

Notes: (A) Clearance of blood during Al-hijamah. External pressure applied through sucking cups helps filtration of small molecules through fenestrated skin capillaries. Small molecules in iron overload include iron, ferritin, liberated hemoglobin, and debris of hemolyzed or fragmented blood cells. (B) Collected coagulated bloody fluids excreted through Al-hijamah. (C) Filtered fluids (plasma-like) coming out through shartat mihjam with repeated skin suctions.

Abbreviation: RBC, red blood cell. 
reported in the evidence-based Taibah theory (Taibah mechanism). ${ }^{1,18}$

Al-hijamah is more comprehensive than the worldwide traditional WCT. ${ }^{1,18}$ Detailed differences between Al-hijamah and traditional WCT were previously reported. ${ }^{11,18}$ In traditional WCT, skin scarifications are done on the surface of the intact skin (not uplifted skin), which may produce pain during the procedure (due to lack of the hypothetic or anaesthetic effect gained during the first suction step). Moreover, lack of the first suction step in traditional WCT (present in Al-hijamah) prevents the formation of a fluid barrier that creates a mechanical barrier between the superficial skin layers and the dermal capillaries. That fluid barrier created during the first step of Al-hijamah separates the fenestrated dermal capillaries from the skin surface (Figure 4A) and protects the dermal capillaries from damage or injury during the superficial skin scarifications. Based on this, the possibility of injuring the fenestrated dermal capillaries using superficial scarifications during traditional WCT is greater than the possibility of injuring dermal capillaries with superficial scarifications during Al-hijamah. It is important to decide which type of WCT (Al-hijamah or traditional WCT) was done when writing or reading research articles about WCT. Some authors may write WCT when Al-hijamah is meant in the methodology section, ${ }^{27}$ which may confuse the reader.

\section{Proper practice, precautions, contraindications, and side effects of Al-hijamah}

Al-hijamah is a safe therapeutic procedure when practiced properly by a qualified, well-trained, and licensed practitioner. It is rare to face side effects when the criteria for proper practice of Al-hijamah are fulfilled. Strict sterilization is a must in the beginning, throughout the whole procedure, and at the end of Al-hijamah. The most important precaution is to take care regarding selecting the best anatomical sites for cup application. ${ }^{28}$ It is essential to practice Al-hijamah in specialized clinics in hospitals. In addition, moderate suction pressure inside cups (less than $-300 \mathrm{mmHg}$ ) for 5 minutes is the best. It is better if Al-hijamah is not practiced near the course of superficial veins or nerves to guard against injury to those structures. It is not advisable to practice Al-hijamah in patients with high-risk pregnancy, recent burns (inflamed tissues), or attacks of severe bleeding. Circulatory shock, uncontrolled bleeding disorders, uncontrolled coagulation disturbances, conditions of severe anemia, and conditions of active bleeding are relative contraindications for performing Al-hijamah. Once the abovementioned conditions are corrected and the patient's condition improves, Al-hijamah can be practiced when there is a strong therapeutic indication, taking into account the risk/benefit ratio. When Al-hijamah is highly indicated at some special anatomical sites (near the course of superficial veins or nerves), risk/benefit ratio should be applied and Al-hijamah should be done using Salah's technique ${ }^{28}$ (Figure 3C) for safe practice of Al-hijamah where a skin fold of the skin uplifting is pinched out between the thumb and index fingers of the left hand to make sure that it is away from the underlying anatomical structures while the right hand makes superficial scarifications in the pinched-out skin fold. The suction step should be manual using a handheld pump ${ }^{11}$ and should not be done using cotton or alcohol ignition to avoid skin burns or fire accidents. Suction time should be about 5 minutes, and suction pressure should be moderate (three to four maximal suction times using the handheld pump).

Shartat mihjam (Figures 3A, B and 4A) is an Arabic term that means superficial skin scarifications $(0.1 \mathrm{~mm}$ in depth to preserve the structure of the superficial fenestrated dermal capillaries) that are confined to the skin dome (skin uplifting created after the first suction step). Skin scarifications of Al-hijamah denote the hand skills that differentiate one skillful practitioner from another. Skin scarifications should be multiple, longitudinal (1-2 mm in length; ie, not pinpoint pricks), in parallel rows, equally distributed, and productive. Malpractice of Al-hijamah is caused by any violation of those criteria and may carry side effects. Practitioner skill is required to do shartat mihjam properly for better blood clearance benefits that can be evaluated and quantitated using the previously mentioned indices of Al-hijamah. Frequency of performing Al-hijamah varies according to disease condition and response to treatment. It can be done every other week, monthly, twice per year, or yearly. Every case should be individualized according to the patient's condition and follow-up in light of current treatment.

There are no absolute contraindications for practicing Alhijamah. Proper practice of Al-hijamah necessitates the presence of an experienced practitioner to perform Al-hijamah and an eligible patient having a disease condition that will benefit from treatment using Al-hijamah. Al-hijamah can be done for both preventive and therapeutic health purposes. ${ }^{11,28}$ Al-hijamah should be done in a sterile, well-equipped environment (hospital or specialized clinic) using the triple $\mathrm{S}$ steps (suction, scarification, and suction) of Al-hijamah. In the vast majority of cases, Al-hijamah is done by applying sucking cups on points on the back of the trunk. ${ }^{28}$ This carries the advantages of a simpler technique (the flat surface of 
the back is easier for large cup application for better blood clearance) and cosmetic benefit (the back is a hidden area covered by clothes).

The most important points of malpractice causing possible side effects include deep skin scarifications $(>0.5 \mathrm{~mm}$ in depth) causing damage of the superficial fenestrated capillaries (causing disturbed Al-hijamah-induced filtration function), long skin incisions causing bleeding, large skin incisions causing postcupping scars, strong suction pressure ( $\geq 300 \mathrm{mmHg}$ ) may cause skin ecchymosis and Taibah sign, ${ }^{11}$ suction using cotton ignition may burn the skin, prolonged suction time causing skin ecchymosis, and pinpoint pricks causing inefficient clearance function. However, after the acute condition improves, re-evaluation of the patient's general condition is needed before practicing Al-hijamah where the risk/benefit ratio should be applied. In the literature, side effects of cupping therapy were mainly related to malpractice of traditional DCT and traditional WCT, but not Al-hijamah. As the methodology is similar in all three, reported side effects should be considered and should be divided into common and rare side effects.

Common side effects include skin bruises, Taibah sign ${ }^{11}$ (due to excessive suction pressure or prolonged suction duration causing dermal capillary rupture), bleeding (due to deep or long skin scarification), keloid scarring, and burns (when using cotton or alcohol ignition). Rare serious side effects may include acquired hemophilia $\mathrm{A},{ }^{29}$ hemorrhagic stroke, ${ }^{30}$ factitious panniculitis, ${ }^{31}$ reversible cardiac hypertrophy, and iron deficiency anemia (due to too frequent sessions of traditional WCT with extensive bleeding caused by an unqualified practitioner). ${ }^{32,33}$

\section{Pathophysiology of iron overload and hyperferremia}

Iron overload is a major health problem in thalassemia, hemochromatosis, sickle cell anemia, sideroblastic anemia, and others that may cause tissue damage (involving the heart, liver, skin, pancreas, and endocrine glands, among others) and serious complications in children and adults. Mean iron level in the skin of thalassemia patients increased by more than $200 \%{ }^{13}$ Treatment of iron overload using iron chelation therapy is vital. Long-term treatment using deferoxamine, deferiprone, and deferasirox (at full doses) may carry intolerable side effects (eg, decreased immunity due to neutropenia, agranulocytosis, renal disturbances, and gastrointestinal disturbances) requiring drug discontinuation in $30 \%$ of patients. ${ }^{34}$ Unfortunately, iron overload persists as a cause of morbidity even after curing thalassemia with bone marrow transplantation. ${ }^{35}$ The blood clearance percentage of iron and ferritin is a good parameter for treating iron overload, taking into account other health and economic burdens of treatment.

\section{Mechanisms of hemolysis in thalassemia}

Mechanisms of hemolysis in thalassemia (an example of iron overload) need careful understanding, medical education, and evaluation, being the source of iron (from liberated hemoglobin of hemolyzed cells) in addition to the increased intestinal absorption of iron. Hemolysis in thalassemia is multifactorial in origin; eg, due to precipitation of globin chains in the erythrocytes, erythrocyte membrane skeletal protein defects, ${ }^{36}$ presence of natural antigalactosyl IgG antibodies on thalassemic erythrocytes, ${ }^{37}$ alloimmunization (or erythrocyte autoimmunization due to autoantibodies) in transfusion-dependent thalassemic patients, ${ }^{37}$ sensitivity of thalassemic erythrocytes to oxidative stress (due to increased oxidants as malondialdehyde and decreased antioxidants as polyunsaturated fatty acids), ${ }^{36}$ and excessive oxidation of the unstable globin chains with subsequent release of oxygen-free radicals. ${ }^{36}$ Red blood cell destruction by human monocytes may be related to changes in the intracellular iron and ferritin concentrations and phenotype. ${ }^{38}$

Complications of excessive frequent blood transfusions and excessive hemolysis may aggravate the iron overload condition and may cause blood-borne infections such as viral hepatitis (C or B). Unfortunately, iron chelation therapy does not treat the abovementioned causes of hemolysis.

Iron is high in the interstitial fluids and in the serum of iron overload patients. This may be explained by the fact that interstitial fluid is formed by filtration of capillary blood at the arterial ends of capillaries and is absorbed later at the venous ends of capillaries. ${ }^{1,18}$ Moreover, the pathophysiology of pulmonary hypertension in beta-thalassemia may be mediated through iron overload, reduced bioavailability of nitric oxide, hemolysis, and hypercoagulopathy. ${ }^{39}$ As skin iron deposition is high in iron overload, treatment modalities using percutaneous iron excretion may be promising.

\section{Oxidative and pathological roles exerted by excess serum iron and ferritin}

Iron is a major oxidant in vivo. ${ }^{40}$ Iron-induced generation of reactive oxygen species is responsible for the damaging effects induced by iron released by isoferritins (containing iron) on lymphocyte functions. ${ }^{41}$ Iron overload causes oxidative stress, 
Table I Reported pathological roles of ferritin in iron overload conditions; eg, thalassemia

In thalassemic patients without hepatitis viral infection:

High serum ferritin is:

- An index of liver iron overload in thalassemia patients (not having viral hepatitis or ascorbic acid deficiency). ${ }^{78}$

- Associated with immunological suppression. ${ }^{48}$

- Associated with increased growth rates of cancer cells and infectious organisms. ${ }^{48}$

In thalassemic patients with hepatitis viral infection:

High serum ferritin is:

- Closely related to the liver iron concentration. Adequate chelation therapy usually protects against liver fibrosis. ${ }^{79}$

- Useful in the follow-up of patients receiving long-term transfusional treatment using the ferritin/ALT ratio, especially when acute or chronic liver cell damage may interfere with iron overload by increasing serum ferritin values. ${ }^{80}$

- Associated with hepatitis $C$ virus infection (causing raised AST activity and serum ferritin concentration compared with seronegative patients). ${ }^{81}$

- Significantly associated with the hepatic fibrosis. ${ }^{82}$

- A risk factor (with serum triglycerides and total cholesterol) for impaired glucose tolerance and diabetes mellitus. ${ }^{83}$

- Associated with hepatitis $C$ virus antibody positivity and HCV-RNA by PCR. ${ }^{84,85}$

- Associated with high liver transaminases (ALT, AST), anti-HCV seropositivity, raised liver transaminases, hemochromatosis status, and liver fibrosis. ${ }^{84-89}$

- Associated with viral hepatitis (genotype I) with higher rate of splenectomy. ${ }^{90}$

- Observed in patients with TTV-HCV coinfection compared with patients with TTV infection alone. ${ }^{91}$

- Accounting in part for the enlargement of hepatoduodenal ligament nodes in thalassemia. ${ }^{92}$

Low serum ferritin is:

- Associated with sustained virological response to ribavirin. ${ }^{93}$

- Reported in complete responders to interferon therapy compared with the values for partial and nonresponders before starting therapy. ${ }^{94}$

- Observed in patients who responded to interferon-alpha monotherapy. ${ }^{95}$

Abbreviations: ALT, alanine aminotransferase; AST, aspartate aminotransferase; $\mathrm{HCV}$, hepatitis C virus; PCR, polymerase chain reaction; RNA, ribonucleic acid; TTV, Torque teno virus.

depletion of endogenous antioxidants, and lipid peroxidative damage..$^{42}$ Iron may induce the formation of the major atherogenic factor (oxidized LDL), causing atherosclerosis (Table 1). Serum cholesterol was reported to increase iron deposits that could be identified in the arterial walls in conditions of experimental hypercholesterolemia and in iron-overloaded hypercholesterolemia. Lipoperoxides in liver and spleen homogenates were high in conditions of iron overload. ${ }^{40}$

Moreover, young thalassemic patients showed an atherogenic lipid profile where serum triglycerides, total cholesterol, apolipoprotein A, and carotid intima-media thickness (CIMT) were significantly elevated. Serum high-density lipoprotein (HDL) was significantly lowered. In thalassemic patients,
CIMT was positively correlated with age, hemoglobin $\mathrm{F}$ ( $\mathrm{Hb}$ F), ferritin, and cholesterol levels. ${ }^{40,43}$ Interestingly, both serum iron and triglycerides may be involved in the pathogenesis of LDL oxidation, as evidenced by the report that high levels of oxidized LDL antibodies promoted atherosclerosis in patients with beta-thalassemia. ${ }^{44}$ That was confirmed by another report in which iron was a potent catalyst of oxidative reactions and macrophage-mediated LDL oxidation in atherogenesis. ${ }^{45}$ In addition, released heme may have injurious effects that result from its potent catalysis of LDL oxidation. ${ }^{46}$ Moreover, circulating iron stores (serum ferritin) were reported to be associated with vascular damage in patients with nonalcoholic fatty liver disease. ${ }^{47}$

\section{Iron overload suppresses patients' immunity}

Iron overload is usually associated with hyperferremia in conditions of beta-thalassemia major, dyserythropoiesis, hereditary hemochromatosis, and chronic diffuse liver diseases; eg, cirrhosis and chronic hepatitis. This may cause the formation of antiferritin antibodies and circulating immune complexes. Increased body stores of iron may affect the immunoregulatory balance, resulting in increased growth rates of cancer cells, infectious organisms, and opportunistic pathogens. Iron overload may complicate the clinical management of pre-existing acute and chronic diseases. ${ }^{48}$ Iron and ferritin impaired a variety of immunological functions. Ferritin-associated iron induced neutrophil dysfunction in hemosiderosis. ${ }^{49}$ Iron overload, especially with hyperferremia, may exert an immune-suppressing effect through altering the distribution of $\mathrm{T}$ lymphocytes in various compartments of the immune system, ${ }^{50}$ suppressing the immunological functions of the complement system (classic and alternative pathways), decreasing the $\mathrm{T}$ helper (CD4) proliferative capability, decreasing T helper numbers, decreasing $\mathrm{T}$ helper activity, increasing the $\mathrm{CD} 8 / \mathrm{CD} 4$ ratios, impairing the generation of cytotoxic $\mathrm{T}$ cells, enhancing the suppressor $\mathrm{T}$ cell numbers and activity, suppressing the antibody-mediated and mitogen-stimulated phagocytosis (by monocytes and macrophages), inducing alterations in the T lymphocyte subsets, inducing modification of lymphocyte distribution in different immunological locations, and altering immunoglobulin secretion. ${ }^{48-54}$

There is a reported progressive dysfunction of monocytes associated with iron overload in patients with thalassemia major. ${ }^{51}$ Moreover, there is an impaired neutrophil defense against Yersinia enterocolitica in patients with iron overload who are undergoing dialysis. ${ }^{52-54}$ 
Negative correlations between $\mathrm{T}$ helper/T cytotoxic ratio and malondialdehyde levels were obtained in the blood and spleen tissues during experimental iron overload, indicating that lipid peroxidation may play a role in the immunological abnormalities observed in experimental hemosiderosis. ${ }^{53}$ Secondary hemosiderosis may be accompanied by a decrease in the phagocytic functions of neutrophils, as evidenced by the report that neutrophils from patients with secondary hemosiderosis contain excessive amounts of autotoxic iron and have increased cellular iron and ferritin content. ${ }^{49}$ Iron concentrations were four to five times more elevated in secondary hemosiderosis than in healthy subjects. This iron accumulation may be toxic for neutrophils and may explain the three-fold higher risk of bacteremia reported in those patients. ${ }^{51-54}$

Infections with virulent pathogens are commonly encountered in patients having iron overload; eg, Listeria monocytogenes meningitis. ${ }^{55}$ Although iron-binding proteins such as transferrin and lactoferrin are bacteriostatic in vitro, ${ }^{56-58}$ iron overload may disturb the bacteriostatic functions of these proteins and decrease their antimicrobial activity, resulting in increased incidence of infections. ${ }^{56,59-61}$ Subclinical atherosclerosis in children with major beta-thalassemia begins early in life and these children are at risk of developing premature atherosclerosis. ${ }^{62}$

\section{Phlebotomy versus Al-hijamah for treating iron overload}

After successful marrow transplantation, iron overload is still an important cause of morbidity in thalassemia. Phlebotomy is a safe, efficient, and widely accepted method where mobilization of iron from overloaded tissues occurs, causing a decrease in iron overload in exthalassemic patients. Phlebotomy was reported to decrease serum ferritin and liver iron concentration maximally and significantly. It also improved the histological grading for chronic hepatitis in ex-thalassemic patients. ${ }^{63}$ Phlebotomy (versus iron chelation therapy) is still practiced as the therapeutic procedure aiming at getting rid of a portion of blood to excrete an abnormally increased offending blood component. Phlebotomy is the initial treatment of choice in hemochromatosis, while iron chelation therapy is the treatment of choice for transfusional siderosis encountered in thalassemia ${ }^{64} \mathrm{~A}$ phlebotomy program was reported to be beneficial for two-thirds of patients who underwent allogeneic hematopoietic stem cell transplantation for treating thalassemia. ${ }^{65}$ Thalassemia patients (who received bone marrow transplant) with subclinical left ventricular diastolic dysfunction and impaired left ventricular contractility may reverse these processes with an effective regimen of iron reduction using phlebotomy. ${ }^{66}$ Interestingly, cure of thalassemia in some hepatic cirrhosis patients with allogeneic bone marrow transplantation resulted in reversibility of liver cirrhosis after iron removal treatment where serum aminotransferase levels decreased, histologic inflammatory activity decreased, and histological biopsies showed regression of incomplete or definite cirrhosis. ${ }^{67}$ Phlebotomy may treat iron overload but it may cause significant blood loss, causing aggravation of the anemic status in patients having thalassemia or sickle cell anemia. Blood shed out during phlebotomy may benefit patients by decreasing the level of serum ferritin, iron, antibodies, and hemolyzed cells, but the necessity for a second blood transfusion consequently increases. Elevated erythrocyte ferritin during phlebotomy therapy in iron overload depends on the body iron stores that can be regulated by the activity of erythropoiesis. ${ }^{68}$

However, phlebotomy was not reported to treat the abovementioned causes of hemolysis in thalassemic patients. As for Al-hijamah, it may treat some causes of hemolysis; eg, through excretion of immunoglobulin antibodies and noxious substances. Al-hijamah-induced percutaneous excretion of iron and ferritin ${ }^{2}$ may improve the therapeutic outcomes in iron overload patients (Table 2). Al-hijamah may induce pharmacological potentiation ${ }^{3}$ (decreasing the needed dose and frequency of iron chelation drug administration and causing decreased drug-induced side effects). Al-hijamah may enhance the natural immunity ${ }^{3}$ and enhance the removal of cellular fragments of hemolyzed cells. Reported WCT-induced blood clearance of antibodies ${ }^{3}$ may treat some causes of hemolysis and benefit iron overload patients. Al-hijamah may decrease the needed frequency (and amount) of blood transfusions. Al-hijamah-induced reduction in blood pressure and blood clearance of triglycerides, LDL cholesterol, and total cholesterol ${ }^{2}$ may prevent and treat disease conditions associated with thalassemia, such as premature atherosclerosis, and improve the general status in hepatitis patients.

Interestingly, Al-hijamah efficiently treated other diseases, including rheumatoid arthritis, ${ }^{3}$ headache, ${ }^{26}$ hypertension, ${ }^{1}$ and bronchial asthma ${ }^{5}$ (Tables 3 and 4). Reported therapeutic benefits of production of endogenous nitric oxide (antioxidant, antimicrobial, and vasodilator) ${ }^{1,6}$ may benefit thalassemia patients. Serum iron, serum ferritin, necessity, and frequency of repeated blood transfusions should be compared before and after Alhijamah. Al-hijamah was reported to improve the oxygen 
Table 2 Al-hijamah versus phlebotomy for treating iron overload

\begin{tabular}{|c|c|c|}
\hline & Phlebotomy & Al-hijamah \\
\hline Nature & Excretory therapeutic procedure & Excretory therapeutic procedure \\
\hline Route of excretion & Venesection & Percutaneous excretion \\
\hline Correcting causes of hemolysis & Less powerful & Powerful \\
\hline Medical principles & $\begin{array}{l}\text { Removal of a significant portion of whole } \\
\text { blood in blood transfusion bags to decrease } \\
\text { the concentration of an offending component }\end{array}$ & $\begin{array}{l}\text { - Percutaneous nonspecific pressure-dependent and size- } \\
\text { dependent filtration of blood through the fenestrated skin } \\
\text { capillaries } \\
\text { - Causes blood clearance from pathological substances }\end{array}$ \\
\hline Indications & $\begin{array}{l}\text { Therapeutic indications } \\
\text { To treat polycythemia and iron overload } \\
\text { conditions; eg, thalassemia }\end{array}$ & $\begin{array}{l}\text { Both preventive and therapeutic indications; eg, pain } \\
\text { conditions, blood diseases, cardiovascular diseases, } \\
\text { neuropsychiatric conditions and others }{ }^{1,28}\end{array}$ \\
\hline Side effects & $\begin{array}{l}\text { - Excessive removal of blood may cause } \\
\text { anemia } \\
\text { - Phlebotomy may aggravate anemic state in } \\
\text { thalassemia patients }\end{array}$ & $\begin{array}{l}\text { - Reversible circular bruises that disappear within few days } \\
\text { - Skin vesicles and Taibah sign (sign of malpractice due to } \\
\text { prolonged cup application) } \\
\text { - Iron deficiency anemia due to excessive traditional WCT } \\
\text { was reported }^{4}\end{array}$ \\
\hline Repeating the procedure & Repeatable according to indication & Repeatable according to indication (every 2 weeks to I year) \\
\hline Nature of excretion & Whole blood & $\begin{array}{l}\text { Bloody fluid (containing a mixture of collected interstitial } \\
\text { fluids, filtered capillary fluids, excreted pathological substances, } \\
\text { and some blood cells) }{ }^{1-3,13}\end{array}$ \\
\hline Degree of loss of blood cells & Whole blood loss & More selective (loss of lesser amount of the red blood cell mass) \\
\hline Steps & $\begin{array}{l}\text { Bleeding in a blood collection bag to remove } \\
\text { about } 500 \mathrm{cc} \text { blood }\end{array}$ & $\begin{array}{l}\text { Skin suction, scarification and second suction (triple S } \\
\text { technique) }\end{array}$ \\
\hline Place for receiving treatment & Hematology department in hospitals & Outpatient clinic or home \\
\hline $\begin{array}{l}\text { Treatment of associated disease } \\
\text { conditions }\end{array}$ & No report & $\begin{array}{l}\text { Reported to treat viral hepatitis, hypertension, hyperlipidemia, } \\
\text { pain conditions, and others }{ }^{1,18,28}\end{array}$ \\
\hline Other therapeutic benefits & None & $\begin{array}{l}\text { Improves local circulation, analgesia, hematological benefits, } \\
\text { and others } 1,18,28\end{array}$ \\
\hline Pharmacological potentiation effect & No report & Reported $^{3}$ \\
\hline Duration of the procedure & Few minutes & $0.5-1$ hour \\
\hline Clearance of skin iron & None & Yes \\
\hline Other names & Fasd (in Arabic), bloodletting & Cupping bloodletting, WCT of prophetic medicine \\
\hline Separation of noxious substances & Not done & Done \\
\hline from blood & $\begin{array}{l}\text { There is only excretion of a significant } \\
\text { portion of blood containing a portion of } \\
\text { noxious substances }\end{array}$ & $\begin{array}{l}\text { There is excretion of noxious substances selectively in a } \\
\text { pressure-dependent and size-dependent manner (similar to } \\
\text { renal glomerular filtration) with loss of a minimal portion of } \\
\text { red blood cells }\end{array}$ \\
\hline Extent of improvement & $\begin{array}{l}\text { Depends on the amount of letted blood } \\
\text { (containing noxious substances) versus } \\
\text { exaggerating the anemic state }\end{array}$ & $\begin{array}{l}\text { Depends on the amount of excreted noxious substances } \\
\text { with proper pressure-dependent filtration and capillary blood } \\
\text { clearance (skill of practice). No exaggeration of the anemic } \\
\text { condition }\end{array}$ \\
\hline
\end{tabular}

Abbreviation: WCT, wet cupping therapy.

saturation and respiratory functions better than phlebotomy in cigarette-smoking patients having chronic obstructive pulmonary disease. ${ }^{27}$

Interestingly, Al-hijamah did not induce anemia or significant blood loss, as evidenced by the normal hematological indices after practicing Al-hijamah. ${ }^{27} \mathrm{Al}$-hijamah (suction, scarification, and suction method) was reported to significantly decrease the level of serum C-reactive protein better than phlebotomy in patients having urticaria and angioedema; ${ }^{69} \mathrm{Al}$-hijamah decreased serum CRP from 11.95 to $1.1 \mathrm{mg} / \mathrm{L}$, while phlebotomy decreased it to a much lower extent. ${ }^{69}$

\section{Reported therapeutic benefits of Al-hijamah during treatment of iron overload}

There are a lot of reported hematological health benefits that can be gained when treating patients having different diseases with Al-hijamah. However, the most attractive reported side effect of repeated traditional WCT is iron deficiency anemia, which can be utilized for treating iron overload conditions. Practicing Al-hijamah was not reported to cause massive blood loss or anemia. Instead, Al-hijamah was reported to reduce serum ferritin significantly. ${ }^{1}$ Although there are no published reported studies about the use of Al-hijamah for treating 
Table 3 Al-hijamah versus iron chelation therapy for treating iron overload

\begin{tabular}{|c|c|c|}
\hline & Iron chelation therapy & Al-hijamah (triple S technique) \\
\hline $\begin{array}{l}\text { Examples and nature } \\
\text { of treatment }\end{array}$ & $\begin{array}{l}\text { - Deferoxamine, deferasirox and deferiprone } \\
\text { - Pharmacological treatments } \\
\text { - Better to be combined with Al-hijamah for treating iron overload }\end{array}$ & $\begin{array}{l}\text { - Al-hijamah is a simple percutaneous } \\
\text { excretory procedure that is distinct from } \\
\text { traditional WCT } \\
\text { - Better to be combined with iron chelation } \\
\text { therapy }\end{array}$ \\
\hline Route of administration & For deferoxamine: & Percutaneous \\
\hline
\end{tabular}

(or method of practice $)^{95-98}$

Mechanism of action $^{95-98}$
Subcutaneous or intravenous as continuous infusion 5-7 days weekly; not orally available; $20-60 \mathrm{mg} / \mathrm{kg} /$ day averaged over a week if not given daily For deferasirox:

Oral, as a suspension, once daily (or in some circumstances divided twice daily); $20-40 \mathrm{mg} / \mathrm{kg} /$ day, highly individualized and is dependent on the transfusion rate For deferiprone:

Oral as tablets, generally in three divided doses; $75 \mathrm{mg} / \mathrm{kg} /$ day

For deferoxamine:

Binds free iron in the blood to enhance its urinary excretion

Removes excess tissue iron; eg, the liver

Affects expression and release of inflammatory mediators by specific cell types ${ }^{60,61}$

For deferasirox:

Selective for iron (as Fe3+)

Binds iron with high affinity in a $2: 1$ ratio

For deferiprone:

Has an affinity for ferric ion (iron III). Deferiprone binds with ferric ions to form neutral complexes that are stable over a wide range of $\mathrm{pH}$ values

Nature of iron excretion

Methodology Pharmacological iron excretion

Indirect iron excretion

Clearance of blood and Reported to clear blood of excess iron and ferritin interstitial fluids

Indications

Iron overload conditions

Route of iron excretion

Frequency of

administration

Tolerability

Duration per a single

treatment

Plasma half-life ${ }^{95-98}$

Other therapeutic

benefits

Urine and stool

Daily

Tolerable in most cases except when allergy or severe side effects develop

For deferoxamine, Infusion takes about 8 hours per session

For deferasirox and deferiprone, treatment is oral

For deferoxamine: Short ( $20-30$ minutes)

For deferasirox: Long (I I-16 hours)

For deferiprone: Intermediate ( 2-3 hours)

None

Therapeutic values of combining Al-hijamah with iron chelation therapy

Treatment of other

diseases or associated

disease
Al-hijamah-induced excretion of iron and ferritin may:

- Improve the therapeutic effects of iron chelators

- Decrease the needed drug doses

- Decrease the frequency of drug administration

- Decrease the duration of scheduled treatment

- Decrease the drug-induced side effects

None
Pressure-dependent, size-dependent nonspecific filtration of blood circulation through the fenestrated dermal capillaries causing nonspecific blood clearance; ${ }^{1,18}$ eg, excretion of iron and ferritin
Physiological pressure-dependent mechanism

Direct iron excretion

Reported to clear both blood and interstitial fluids from excess pathological substances; eg, autoantibodies and ferritin in a nonspecific manner ${ }^{1,13}$

A long list of disease conditions that include pain conditions (eg, back pain), autoimmune diseases (eg, rheumatoid arthritis),

neurological conditions (eg, headache), infections (eg, cellulitis), and others ${ }^{1-3,13,63}$

Percutaneous

Every I-3 months

Tolerable

0.5-I hour

No half-life as Al-hijamah is a minor surgical excretory procedure

Pharmacological potentiation, immunological potentiation, analgesic effect, improvement of microcirculation, and others

Combining iron chelators with Al-hijamah may:

- Potentiate the state of negative iron balance (Fe output $>$ Fe input)

- Mobilize more iron from tissues to blood

- Enhance iron excretion

- Protect vital organs from tissue damage Yes. WCT and Al-hijamah were reported to treat many disease conditions that are different in etiology and pathogeneses

Abbreviation: WCT, wet cupping therapy. 
Table 4 Safety issue of iron chelation therapy versus Al-hijamah

\begin{tabular}{|c|c|c|}
\hline & Iron chelation therapy & Al-hijamah (SSS technique) \\
\hline $\begin{array}{l}\text { Safety of medical } \\
\text { practice }\end{array}$ & $\begin{array}{l}\text { Administration of deferoxamine, deferasirox, and deferiprone } \\
\text { is usually safe but has certain limitations, side effects, } \\
\text { contraindications, and precautions }\end{array}$ & Reported to be safe with negligible side effects \\
\hline Special precautions ${ }^{95-98}$ & $\begin{array}{l}\text { For deferasirox: } \\
\text { Acute renal failure and cytopenias; eg, agranulocytosis, neutropenia, } \\
\text { and thrombocytopenia } \\
\text { For deferiprone: } \\
\text { Hepatic and renal impairment } \\
\text { Neutropenia }\end{array}$ & $\begin{array}{l}\text { Not done during active bleeding or circulatory } \\
\text { shock }\end{array}$ \\
\hline Contraindications & $\begin{array}{l}\text { For deferiprone: } \\
\text { Agranulocytosis, pregnancy, and lactation }\end{array}$ & Shock and active bleeding \\
\hline $\begin{array}{l}\text { Known or theoretical } \\
\text { disadvantages } 95-98\end{array}$ & $\begin{array}{l}\text { For deferoxamine: } \\
\text { - Frequent parenteral administration may not be tolerated } \\
\text { - Local skin reactions } \\
\text { For deferiprone: } \\
\text { - Gastrointestinal or joint symptoms } \\
\text { - Agranulocytosis } \\
\text { - Neutropenia require weekly CBC monitoring } \\
\text { For deferasirox: } \\
\text { - Gastrointestinal symptoms }\end{array}$ & None \\
\hline Common side effects ${ }^{95-98}$ & $\begin{array}{l}\text { For deferoxamine: } \\
\text { Local skin reactions; sensorineural hearing loss, and bone problems } \\
\text { For deferasirox: } \\
\text { Rash gastrointestinal upset, diarrhea, mild abnormalities in } \\
\text { creatinine clearance and proteinuria } \\
\text { For deferiprone: } \\
\text { Gastrointestinal distress, joint pain, and erosive arthritis and } \\
\text { neutropenia }\end{array}$ & $\begin{array}{l}\text { - Reversible circular bruises that disappear } \\
\text { within few days } \\
\text { - Taibah sign (skin vesicles, sign of malpractice } \\
\text { due to prolonged cups application) } \\
\text { - Iron deficiency anemia due excessive bleeding } \\
\text { in traditional WCT was reported }\end{array}$ \\
\hline $\begin{array}{l}\text { Severe and/or dangerous } \\
\text { side effects } 95-98\end{array}$ & $\begin{array}{l}\text { For deferoxamine: } \\
\text { Siderophore for some bacteria (eg, listeria) } \\
\text { Retinopathy and acute pulmonary disease } \\
\text { For deferasirox: } \\
\text { Peptic ulcers, liver dysfunction, renal dysfunction (including failure), } \\
\text { cytopenias } \\
\text { For deferiprone: } \\
\text { Agranulocytosis and hepatic fibrosis }\end{array}$ & $\begin{array}{l}\text { Acquired hemophilia A, factitious panniculitis, and } \\
\text { stroke were reported rarely with malpractice of } \\
\text { traditional WCT but not with Al-hijamah }\end{array}$ \\
\hline Drug interactions $\mathrm{s}^{95-98}$ & $\begin{array}{l}\text { Avoid using deferiprone with aluminum-containing antacids, as it } \\
\text { can chelates trivalent metal ions }\end{array}$ & $\begin{array}{l}\text { - No drug-drug interaction occurs as Al-hijamah } \\
\text { is a mechanical minor surgical procedure } \\
\text { - Excretion of pathological substances through } \\
\text { Al-hijamah helps gaining better pharmacological } \\
\text { therapeutic effects }\end{array}$ \\
\hline
\end{tabular}

Abbreviations: $C B C$, complete blood count; SSS, triple S technique; WCT, wet cupping therapy.

thalassemia or conditions of iron overload, the safety of practicing Al-hijamah and the reported health benefits associated with it ${ }^{11}$ may be an attractive topic for hematologists and researchers to explore. The therapeutic benefits of Al-hijamah for treating different disease conditions have been previously reported. ${ }^{11}$ Many of those health and therapeutic benefits are helpful when treating patients having iron overload with hemolysis; for example, thalassemia. Al-hijamahinduced immunological enhancement (eg, physiological leukocytosis and increased count of NK cells ${ }^{3,11}$ ) is beneficial for improving the poor immunity status in thalassemia patients. Blood and interstitial fluid clearance from excess ferritin and iron is the single most important therapeutic benefit of Al-hijamah when treating thalassemia patients. Being a percutaneous excretory procedure, skin (a site for iron deposition) clearance of excessive iron can be gained through Alhijamah. Moreover, nonspecific blood clearance gained during Al-hijamah, where patients' serum can be cleared significantly of LDL cholesterol, total cholesterol, and triglycerides, ${ }^{1}$ may protect thalassemia patients against the development of premature atherosclerosis. Pharmacological potentiation reported when combining Al-hijamah with different drug treatments 
may enhance the therapeutic effects and decrease the side effects of concomitantly administered drugs by iron overload patients, such as iron chelation therapy. Importantly, Alhijamah was not reported to cause massive bleeding (red blood cell loss $)^{26,27}$ or aggravate anemic status. Al-hijamah induces possible nonspecific blood clearance of liberated hemoglobin and fragments of hemolyzed cells (having small particle sizes that can be filtered through capillary pores).

\section{Al-hijamah combined with oral honey for treating hyperferremia and its complications}

Consumption of oral honey was reported to provide numerous beneficial effects that may expand the therapeutic effects of Al-hijamah when combined with Al-hijamah. Oral honey may benefit thalassemia and iron overload patients, especially thalassemia cases complicated with diabetes mellitus, poor immunity, and oxidative stress-induced effects; oral honey improved body weight and serum lipid profile of diabetic patients ${ }^{70}$ to the extent that it was recommended to be used as a sugar substitute in patients with type 1 diabetes mellitus ${ }^{71}$ or impaired glucose tolerance. ${ }^{72}$ Patients having impaired glucose tolerance exhibited significant lower plasma glucose concentrations after consumption of oral honey where the plasma glucose levels peaked at 30-60 minutes in response to oral honey and showed a rapid decline as compared to patients consuming glucose, which indicated a better control of the glycemic index with oral honey administration. ${ }^{72}$ Oral honey consumption was reported to increase serum antioxidant capacity, vitamin $\mathrm{C}$ concentration, beta-carotene, and glutathione reductase. Interestingly, honey reduced plasma ferritin by $11 \%{ }^{73}$ Moreover, oral honey was reported to enhance the natural immunological response through increasing the monocytes and lymphocytes percentage, decreasing serum immunoglobulin $\mathrm{E}^{73}$ and stimulating antibody production during primary and secondary immune responses against thymus-dependent and thymus-independent antigens. ${ }^{74}$

Interestingly, oral honey ingestion was reported to decrease prostaglandins levels, elevate nitric oxide production, and improve the hematological and biochemical tests in a patient with a long history of AIDS. ${ }^{75}$ It might be concluded that combining Al-hijamah with oral honey may improve the therapeutic outcomes in thalassemia and iron overload patients. Interestingly, in prophetic medicine, both Al-hijamah and oral honey are curative remedies according to the prophetic teaching: "Cure is in three: in sharat mihjam, gulp of honey (oral honey), and cauterization. I do not recommend my nation to cauterize." ${ }^{\prime 76,77}$

\section{Conclusion}

In conclusion, Al-hijamah is a beneficial, safe, economic, time-saving (about 30 minutes), and repeatable treatment modality. Al-hijamah may be a good combinatory treatment with iron chelation therapy, and can be a sole treatment when there is a limitation or contraindication to iron chelation therapy. Al-hijamah may be superior to phlebotomy, and it needs to be researched further for educational evaluation in treating iron overload. Oral honey also carries a lot of therapeutic health benefits when treating conditions of iron overload. This may strongly suggest Al-hijamah combined with oral honey as a novel treatment for thalassemia and iron overload conditions may potentiate therapeutic effects of iron chelation therapy.

\section{Acknowledgments}

We are so grateful to the helpful revision and grammatical corrections exerted by Professor Antar Abdellah, Associate Professor of English Language and Linguistics in the Faculty of Education at Taibah University, Al-Madinah Al-Munawwarah, Saudi Arabia.

\section{Disclosure}

The authors declare no conflict of interest in this work.

\section{References}

1. El Sayed SM, Mahmoud HS, Nabo MMH. Medical and scientific bases of wet cupping therapy (Al-hijamah): in light of modern medicine and prophetic medicine. Altern Integ Med. 2013;2(3):1-16.

2. Alshowafi FK. Effect of blood cupping on some biochemical parameter. Med J Cairo Univ. 2010;78:311-315.

3. Ahmed SM, Madbouly NH, Maklad SS, Abu-Shady EA. Immunomodulatory effects of blood letting cupping therapy in patients with rheumatoid arthritis. Egypt J Immunol. 2005;12(2):39-51.

4. Yun GW, Yang YJ, Song IC, et al. A prospective evaluation of adult men with iron-deficiency anemia in Korea. Intern Med. 2011;50(13): 1371-1375.

5. Zhang CQ, Liang TJ, Zhang W. [Effects of drug cupping therapy on immune function in chronic asthmatic bronchitis patients during protracted period]. Zhongguo Zhong Xi Yi Jie He Za Zhi. 2006;26(11): 984-987. Chinese.

6. Cals-Grierson MM, Ormerod AD. Nitric oxide function in the skin. Nitric Oxide. 2004;10(4):179-193.

7. Boissel JP, Ohly D, Bros M, Gödtel-Armbrust U, Förstermann U, Frank $\mathrm{S}$. The neuronal nitric oxide synthase is upregulated in mouse skin repair and in response to epidermal growth factor in human $\mathrm{HaCaT}$ keratinocytes. J Invest Dermatol. 2004;123(1):132-139.

8. Rendell MS, Johnson ML, Smith D, et al. Skin blood flow response in the rat model of wound healing: expression of vasoactive factors. J Surg Res. 2002;107(1):18-26.

9. Lee RH, Efron D, Tantry U, Barbul A. Nitric oxide in the healing wound: a time-course study. J Surg Res. 2001;101(1):104-108.

10. Wink DA, Miranda KM, Espey MG, et al. Mechanisms of the antioxidant effects of nitric oxide. Antioxid Redox Signal. 2001;3:203-213.

11. El Sayed SM, Al-quliti A, Mahmoud HS, et al. Therapeutic benefits of Al-hijamah: in light of modern medicine and prophetic medicine. AJMBR. 2(2):46-71. 
12. Kanitakis J. Anatomy, histology and immunohistochemistry of normal human skin. Eur J Dermatol. 2002;12:390-399.

13. El Sayed SM, Abou-Taleb A, Mahmoud HS, et al. Percutaneous excretion of iron and ferritin (through Al-hijamah) as a novel treatment for iron overload in beta-thalassemia major, hemochromatosis and sideroblastic anemia. Med Hypotheses. 2014;83(2):238-246.

14. Saladin KS. The circulatory system: blood vessels and circulation. In: Anatomy and Physiology: The Unity of Form and Function. 3rd ed. New York: McGraw-Hill, 2003:756-781.

15. Bouwstra JA, Honeywell-Nguyen PL, Gooris GS, Ponec M. Structure of the skin barrier and its modulation by vesicular formulations. Prog Lipid Res. 2003;42(1):1-36.

16. Young B, Heath JW. Skin. In: Wheater's Functional Histology: A Text and Colour Atlas, 4th ed. London: Churchill Livingstone, 2000:164.

17. Huber R, Emerich M, Braeunig M. Cupping - is it reproducible? Experiments about factors determining the vacuum. Complement Ther Med. 2011;19(2):78-83.

18. El Sayed SM, Mahmoud HS, Nabo MMH. Methods of Wet Cupping Therapy (Al-hijamah): In Light of Modern Medicine and Prophetic Medicine. Altern Integ Med. 2013;2:1-16.

19. Michalsen A, Bock S, Lüdtke R, et al. Effects of traditional cupping therapy in patients with carpal tunnel syndrome: a randomized controlled trial. J Pain. 2009;10(6):601-608.

20. Kim JI, Kim TH, Lee MS, et al. Evaluation of wet-cupping therapy for persistent non-specific low back pain: a randomised, waiting-list controlled, open-label, parallel-group pilot trial. Trials. 2011;12:146.

21. Xu J, Lin R, Wang J, et al. Effect of acupuncture anesthesia on acne vulgaris of pricking-bloodletting cupping: a single-blind randomized clinical trail. J Tradit Chin Med. 2013;33(6):752-756.

22. Zhang SJ, Liu JP, He KQ. Treatment of acute gouty arthritis by bloodletting cupping plus herbal medicine. J Tradit Chin Med. 2010;30(1): $18-20$.

23. Erqing D, Haiying L, Zhankao Z. One hundred and eighty-nine cases of acute articular soft tissue injury treated by blood-letting puncture with plum-blossom needle and cupping. J Tradit Chin Med. 2005;25(2):104-105.

24. Pan H. Thirty-two cases of acne treated with blood-letting puncture, cupping and Chinese-drug facemask. J Tradit Chin Med. 2005;25(4) 270-272.

25. Huang YL. [Cupping-bloodletting therapy of Saudi Arabia and its clinical application]. Zhongguo Zhen Jiu. 2008;28(5):375-377. Chinese.

26. Ahmadi A, Schwebel DC, Rezaei M. The efficacy of wet-cupping in the treatment of tension and migraine headache. Am J Chin Med 2008;36(1):37-44.

27. Hekmatpou H, Moeini L, Haji-Nadali S. The effectiveness of wet cupping vs venesection on arterial $\mathrm{O} 2$ saturation level of cigarette smokers: A randomized controlled clinical trial. Pak J Med Sci. 2013;29(6): 1349-1353.

28. Mahmoud HS, Abou-El-Naga M, Omar NAA, El-Ghazzawy HA, Fathy YM, Nabo MMH, et al. Anatomical sites for practicing Wet Cupping Therapy (Al-Hijamah): In Light of Modern Medicine and Prophetic Medicine. Altern Integ Med. 2013;2(8):1-30.

29. Weng YM, Hsiao CT. Acquired hemophilia A associated with therapeutic cupping. Am J Emerg Med. 2008;26(8):970. e1-970. e2.

30. Blunt SB, Lee HP. Can traditional "cupping" treatment cause a stroke? Med Hypotheses. 2010;74(5):945-949.

31. Moon SH, Han HH, Rhie JW. Factitious panniculitis induced by cupping therapy. J Craniofac Surg. 2011;22(6):2412-2414.

32. Kim KH, Kim TH, Hwangbo M, Yang GY. Anaemia and skin pigmentation after excessive cupping therapy by an unqualified therapist in Korea: a case report. Acupunct Med. 2012;30(3):227-228.

33. Lee HJ, Park NH, Yun HJ, Kim S, Jo DY. Cupping therapy-induced iron deficiency anemia in a healthy man. Am J Med. 2008;121(8):e5-e6.

34. Grady RW, Galanello R, Randolph RE, Kleinert DA, Dessi C, Giardina PJ. Toward optimizing the use of deferasirox: potential benefits of combined use with deferoxamine. Haematologica. 2013;98(1):129-135.
35. Angelucci E, Muretto P, Lucarelli G, et al. Phlebotomy to reduce iron overload in patients cured of thalassemia by bone marrow transplantation. Italian Cooperative Group for Phlebotomy Treatment of Transplanted Thalassemia Patients. Blood. 1997;90(3):994-998.

36. Shinar E, Rachmilewitz EA, Lux SE. Differing erythrocyte membrane skeletal protein defects in alpha and beta thalassemia. J Clin Invest. 1989;83(2):404-410.

37. Galili U, Korkesh A, Kahane I, Rachmilewitz EA. Demonstration of a natural antigalactosyl IgG antibody on thalassemic red blood cells. Blood. 1983;61(6):1258-1264.

38. Raha-Chowdhury R, Williams BJ, Worwood M. Red cell destruction by human monocytes - changes in intracellular ferritin concentration and phenotype. Eur J Haematol. 1993;50(1):26-31.

39. Anthi A, Orfanos SE, Armaganidis A. Pulmonary hypertension in $\beta$ thalassaemia. Lancet Respir Med. 2013;1(6):488-496.

40. Araujo JA, Romano EL, Brito BE, et al. Iron overload augments the development of atherosclerotic lesions in rabbits. Arterioscler Thromb Vasc Biol. 1995;15(8):1172-1180.

41. Cardier J, Romano E, Soyano A. Effect of hepatic isoferritins from iron overloaded rats on lymphocyte proliferative response: role of ferritin iron content. Immunopharmacol Immunotoxicol. 1995;17(4):719-732.

42. Gedik GK, Cağlar M, Unal S, Gümrük F. Evaluation of cardiovascular complications with $99 \mathrm{mTc}$ tetrofosmin gated myocardial perfusion scintigraphy in patients with thalassemia major. Rev Esp Med Nucl. 2088;27(3):191-198.

43. Tantawy AA, Adly AA, El Maaty MG, Amin SA. Subclinical atherosclerosis in young beta-thalassemia major patients. Hemoglobin. 2009;33(6):463-474.

44. Brizzi P, Isaja T, D’Agata A, Malaguarnera L, Malaguarnera M, Musumeci S. Oxidized LDL antibodies (OLAB) in patients with betathalassemia major. J Atheroscler Thromb. 2002;9(3):139-144.

45. Yuan XM, Brunk UT. Iron and LDL-oxidation in atherogenesis. APMIS. 1998;106(9):825-842.

46. Jacob HS. Newly recognized causes of atherosclerosis: the role of microorganisms and of vascular iron overload. J Lab Clin Med. 1994;123(6):808-816.

47. Valenti L, Swinkels DW, Burdick L, et al. Serum ferritin levels are associated with vascular damage in patients with nonalcoholic fatty liver disease. Nutr Metab Cardiovasc Dis. 2011;21(8):568-575.

48. Walker EM Jr, Walker SM. Effects of iron overload on the immune system. Ann Clin Lab Sci. 2000;30(4):354-365.

49. Cantinieaux B, Boelaert JR, De Meuleneire J, Kerrels V, Fondu P. Neutrophils from patients with secondary haemosiderosis contain excessive amounts of autotoxic iron. Eur J Haematol. 1993;51(3): 161-165.

50. Cardier JE, Romano E, Soyano A. T lymphocytes subsets in experimental iron overload. Immunopharmacol Immunotoxicol. 1997;19(1):75-87.

51. Ballart IJ, Estevez ME, Sen L, et al. Progressive dysfunction of monocytes associated with iron overload and age in patients with thalassemia major. Blood. 1986;67(1):105-109.

52. Cantinieaux B, Janssens A, Boelaert JR, et al. Ferritin-associated iron induces neutrophil dysfunction in hemosiderosis. J Lab Clin Med. 1999;133(4):353-361.

53. Cardier JE, Romano E, Soyano A. Lipid peroxidation and changes in T lymphocyte subsets and lymphocyte proliferative response in experimental iron overload. Immunopharmacol Immunotoxicol. 1995;17(4):705-717.

54. Cantinieaux B, Boelaert J, Hariga C, Fondu P. Impaired neutrophil defense against Yersinia enterocolitica in patients with iron overload who are undergoing dialysis. J Lab Clin Med. 1988;111(5):524-528.

55. van Asbeck BS, Verbrugh HA, van Oost BA, Marx JJ, Imhof HW, Verhoef J. Listeria monocytogenes meningitis and decreased phagocytosis associated with iron overload. Br Med J (Clin Res Ed). 1982;284(6315):542-544

56. Bullen JJ, Spalding PB, Ward CG, Gutteridge JM. Hemochromatosis, iron and septicemia caused by Vibrio vulnificus. Arch Intern Med. 1991;151(8):1606-1609. 
57. Reiter B, Brock JH, Steel ED. Inhibition of Escherichia coli by bovine colostrum and post-colostral milk. II. The bacteriostatic effect of lactoferrin on a serum susceptible and serum resistant strain of $E$. coli. Immunology. 1975;28(1):83-95.

58. Lawrence TH, Biggers CJ, Simonton PR. Bacteriostatic inhibition of Klebsiella pneumoniae by three human transferrins. Ann Hum Biol. 1977;4(3):281-284.

59. Abbott M, Galloway A, Cunningham JL. Haemochromatosis presenting with a double Yersinia infection. J Infect. 1986;13(2):143-145.

60. Capron JP, Capron-Chivrac D, Tossou H, Delamarre J, Eb F. Spontaneous Yersinia enterocolitica peritonitis in idiopathic hemochromatosis. Gastroenterology. 1984;87(6):1372-1375.

61. Brennan RO, Crain BJ, Proctor AM, Durack DT. Cunninghamella: a newly recognized cause of rhinocerebral mucormycosis. Am J Clin Pathol. 1983;80(1):98-102.

62. Gursel O, Kurekci AE, Tascilar E, et al. Premature atherosclerosis in children with $\beta$-thalassemia major. $J$ Pediatr Hematol Oncol. 2012;34(8):630-634.

63. Angelucci E, Muretto P, Lucarelli G, et al. Treatment of iron overload in the "ex-thalassemic". Report from the phlebotomy program. Ann NY Acad Sci. 1998;850:288-293.

64. Flaten TP, Aaseth J, Andersen O, Kontoghiorghes GJ. Iron mobilization using chelation and phlebotomy. J Trace Elem Med Biol. 2012;26(2-3):127-130.

65. Busca A, Falda M, Manzini P, et al. Iron overload in patients receiving allogeneic hematopoietic stem cell transplantation: quantification of iron burden by a superconducting quantum interference device (SQUID) and therapeutic effectiveness of phlebotomy. Biol Blood Marrow Transplant. 2010;16(1):115-122.

66. Mariotti E, Angelucci E, Agostini A, Baronciani D, Sgarbi E, Lucarelli G. Evaluation of cardiac status in iron-loaded thalassaemia patients following bone marrow transplantation: improvement in cardiac function during reduction in body iron burden. Br J Haematol. 1998;103(4): 916-921.

67. Muretto P, Angelucci E, Lucarelli G. Reversibility of cirrhosis in patients cured of thalassemia by bone marrow transplantation. Ann Intern Med. 2002;136(9):667-672.

68. Bodemann HH, Tanzi-Fetta RF, Schröter-Urban H, Volk BA, Keul J, Löhr GW. Ferritin in erythrocytes and plasma of patients with iron overload. Blut. 1985;51(1):25-31.

69. Sharifi SM, Afrasiabian H. Evaluation of wet cupping treatment in patients with chronic urticaria and angioedema. Open Conf Proc J. 2013;3:1-5.

70. Bahrami M, Ataie-Jafari A, Hosseini S, Foruzanfar MH, Rahmani M, Pajouhi M. Effects of natural honey consumption in diabetic patients: an 8-week randomized clinical trial. Int J Food Sci Nutr. 2009;60(7):618-626.

71. Abdulrhman M, El-Hefnawy M, Hussein R, El-Goud AA. The glycemic and peak incremental indices of honey, sucrose and glucose in patients with type 1 diabetes mellitus: effects on C-peptide level-a pilot study. Acta Diabetol. 2011;48(2):89-94.

72. Agrawal OP, Pachauri A, Yadav H, et al. Subjects with impaired glucose tolerance exhibit a high degree of tolerance to honey. J Med Food. 2007;10(3):473-478.

73. Al-Waili NS. Effects of daily consumption of honey solution on hematological indices and blood levels of minerals and enzymes in normal individuals. J Med Food. 2003;6(2):135-140.

74. Al-Waili NS, Haq A. Effect of honey on antibody production against thymus-dependent and thymus-independent antigens in primary and secondary immune responses. J Med Food. 2004;7(4):491-494.

75. Al-Waili NS, Al-Waili TN, Al-Waili AN, Saloom KS. Influence of natural honey on biochemical and hematological variables in AIDS: a case study. ScientificWorldJournal. 2006;6:1985-1989.

76. Loukas M, Saad Y, Tubbs RS, Shoja MM.The heart and cardiovascular system in the Qur' an and Hadeeth. Int J Cardiol. 2010;140(1):19-23.

77. Al-Bukhari MI. The English Translation of Sahih Al Bukhari. Book of medicine. Chapter of (Cure is in three). Hadeeth numbers 5680-5681. Assryia library, Sayda, Lebanon 2002.
78. Cazzola M, Borgna-Pignatti C, de Stefano P, et al. Internal distribution of excess iron and sources of serum ferritin in patients with thalassemia. Scand J Haematol. 1983;30(4):289-296.

79. Di Marco V, Capra M, Gagliardotto F, et al. Liver disease in chelated transfusion-dependent thalassemics: the role of iron overload and chronic hepatitis C. Haematologica. 2008;93(8):1243-1246.

80. Triadou P, Regnat-Lusinchi A, Girot R. Use of the ferritin/alanine aspartate transaminase ratio as an iron overload marker independent of liver cell damage. Eur J Haematol. 1989;43(5):423-427.

81. Wonke B, Hoffbrand AV, Brown D, Dusheiko G. Antibody to hepatitis $\mathrm{C}$ virus in multiply transfused patients with thalassaemia major. $J$ Clin Pathol. 1990;43(8):638-640.

82. Lai ME, Origa R, Danjou F, et al. Natural history of hepatitis C in thalassemia major: a long-term prospective study. Eur J Haematol. 2013;90(6):501-507.

83. Alavian SM, Miri SM, Tabatabaei SV, et al. Lipid Profiles and Hepatitis C Viral Markers in HCV-Infected Thalassemic Patients. Gut Liver. 2011;5(3):348-355.

84. Omar N, Salama K, Adolf S, El-Saeed GS, Abdel Ghaffar N, Ezzat N. Major risk of blood transfusion in hemolytic anemia patients. Blood Coagul Fibrinolysis. 2011;22(4):280-284.

85. Ameli M, Besharati S, Nemati K, Zamani F. Relationship between elevated liver enzyme with iron overload and viral hepatitis in thalassemia major patients in Northern Iran. Saudi Med J. 2008;29(11): $1611-1615$.

86. Ragab L, Helal S, Zaghloul N, et al. Clinicovirologic analysis of hepatitis $\mathrm{C}$ infection in transfusion-dependent beta-thalassemia major children. Int J Lab Hematol. 2010;32(2):184-190.

87. Sartori M, Andorno S, La Terra G, et al. Evaluation of iron status in patients with chronic hepatitis C. Ital J Gastroenterol Hepatol. 1998;30(4):396-401.

88. Mazza P, Giua R, De Marco S, et al. Iron overload in thalassemia: comparative analysis of magnetic resonance imaging, serum ferritin and iron content of the liver. Haematologica. 1995;80(5):398-404.

89. Agarwal MB, Malkan GH, Bhave AA, et al. Antibody to hepatitis-C virus in multi-transfused thalassaemics - Indian experience. J Assoc Physicians India. 1993;41(4):195-197.

90. Alavian SM, Miri SM, Keshvari M, et al. Distribution of hepatitis C virus genotype in Iranian multiply transfused patients with thalassemia. Transfusion. 2009;49(10):2195-2199.

91. Hu YW, Al-Moslih MI, Al Ali MT, et al. Clinical outcome of frequent exposure to Torque Teno virus (TTV) through blood transfusion in thalassemia patients with or without hepatitis $\mathrm{C}$ virus (HCV) infection. J Med Virol. 2008;80(2):365-371.

92. Chu WC, Metreweli C, Chik KW, Lam WW, Chan YL, Li CK. Enlargement of hepatoduodenal ligament lymph nodes in beta thalassemia children receiving multiple transfusions: a common observation. Haematologica. 2002;87(8):882-884.

93. Tabatabaei SV, Alavian SM, Keshvari M, et al. Low dose ribavirin for treatment of hepatitis $\mathrm{C}$ virus infected thalassemia major patients; new indications for combination therapy. Hepat Mon. 2012;12(6): 372-381.

94. Spiliopoulou I, Repanti M, Katinakis S, Karana-Ginopoulou A, Papanastasiou DA. Response to interferon alfa- $2 b$ therapy in mutitransfused children with beta-thalassemia and chronic hepatitis $\mathrm{C}$. Eur J Clin Microbiol Infect Dis. 1999;18(10):709-715.

95. Telfer PT, Garson JA, Whitby K, et al. Combination therapy with interferon alpha and ribavirin for chronic hepatitis $\mathrm{C}$ virus infection in thalassaemic patients. Br J Haematol. 1997;98(4):850-855.

96. Choi EY, Kim EC, Oh HM, et al. Iron chelator triggers inflammatory signals in human intestinal epithelial cells: involvement of p38 and extracellular signal-regulated kinase signaling pathways. $J$ Immunol. 2004;172(11):7069-7077.

97. Lee HJ, Lee J, Lee SK, Lee SK, Kim EC. Differential regulation of iron chelator-induced IL-8 synthesis via MAP kinase and NF-kappaB in immortalized and malignant oral keratinocytes. BMC Cancer. 2007;7:176.

98. Brittenham GM, Nathan DG, Olivieri NF, et al. Deferiprone and hepatic fibrosis. Blood. 2003;101(12):5089-5090. 
Journal of Blood Medicine

\section{Publish your work in this journal}

The Journal of Blood Medicine is an international, peer-reviewed, open access, online journal publishing laboratory, experimental and clinical aspects of all topics pertaining to blood based medicine including but not limited to: Transfusion Medicine; Blood collection, Donor issues, Transmittable diseases, and Blood banking logistics; Immunohematology; Artificial and alternative blood related medicine; Legal aspects of blood medicine; Historical perspectives. The manuscript management system is completely online and includes a very quick and fair peer-review system. Visit http://www.dovepress.com/ testimonials.php to read real quotes from published authors.

Submit your manuscript here: http://www.dovepress.com/Journal-of-blood-medicine-journal 